\begin{abstract}
This study seeks to explain changes in the proportion of 16 year olds, 17 year olds and 18 year olds who decide to participate in post-compulsory education. Four countries are considered; Germany, the Netherlands, Sweden and England, over as much of the period from 1960 to the present day as data will allow. An initial inspection of the data reveals non-stationarity in virtually all of the series under consideration, so that a cointegration framework is appropriate. The analysis therefore proceeds using the two-stage procedure proposed by Engle and Granger. The results suggest that the key variable that explains the growth in post-compulsory education participation is the increase in prior academic attainment before the end of compulsory schooling. This is the case particularly for females, males being also influenced by the returns available to offering a higher level of education, and the level of real income available to 'spend' on education. The level of youth unemployment seems to play only a small part in the decision as to whether to remain in education.
\end{abstract}

This paper was produced as part of the Centre's Human Resources Programme and the TSER NEWSKILLS Project 
The Demand for Post-Compulsory Education in Four European Countries

Steven McIntosh 
Series Editor: Graham Ingham

Published by

Centre for Economic Performance

London School of Economics and Political Science

Houghton Street

London WC2A 2AE

CC S. McIntosh, 1998

ISBN 0753012200

Individual copy price: $£ 5$ 


\title{
The Demand for Post-Compulsory Education in Four European Countries
}

\author{
Steven McIntosh
}

1. Introduction 1

2. Previous Studies 1

3. The Data 6

4. Estimation 9

$\begin{array}{lll}\text { 5. Results } & 10\end{array}$

i) Order of Integration of Variables $\quad 10$

ii) Long-Run Results 11

$\begin{array}{lll}\text { iii) Interpretations } & 13 & \\ \text { iv) Cointegration Tests } & & 15\end{array}$

v) Short-Run Results 16

$\begin{array}{lll}\text { 6. Conclusion } & 18\end{array}$

$\begin{array}{lr}\text { Figures } & 20\end{array}$

Tables $\quad 23$

Appendix: Data Sources $\quad 29$ 


\section{Acknowledgements}

I would like to thank Ansgar Richter (Germany), Hessel Oosterbeek (Netherlands), Erika Ekstroem and Asa Murray (Sweden), for the considerable work they put into obtaining the data for their respective countries. I have also benefited from useful discussions with Eugenia Kazamaki Ottersten and Hilary Steedman, and from the comments of seminar participants at the CEP and among the NEWSKILLS group.

This paper was produced as part of the NEWSKILLS project, financed by DGXII of the European Commission. The project forms part of the Targeted Socio-Economic Research (TSER) area of Framework Programme IV for Research and Technological Development (RTD).

Steven McIntosh is at the Centre for Economic Performance, London School of Economics. 


\title{
The Demand for Post-Compulsory Education in Four European Countries
}

\author{
Steven McIntosh
}

\section{Introduction}

There follows an attempt to explain movements in the rate of participation in post-compulsory education in four European countries, Germany, the Netherlands, Sweden and England ${ }^{1}$, during the last twenty to thirty years The motivation for the study is to seek explanations for the decision to acquire skills. The rise in demand for skilled labour has been well documented, and it is important to acquire evidence as to whether the supply of skilled labour has also increased, and if so, why.

The very low-skilled group are becoming increasingly marginalised in modern labour markets. Evidence has shown that both the employment levels and earnings of the least well educated are declining relative to those of the most well educated. This is the case particularly in the UK and the US, but is also true to a lesser extent in almost all OECD countries (see Glyn, 1995). It would therefore appear to be clear that, although the proportion of unskilled individuals in the workforce of all countries is falling, it is not falling fast enough to match the declining demand for such individuals. The implication is that young people leaving education at the end of compulsory schooling with no or only low-level qualifications have fewer and fewer opportunities. This does indeed seem to be the case, as described by Blanchflower and Freeman (1996). On the assumption that there is sufficient demand for more skilled workers, it would therefore seem to be important for more young people to obtain a higher level of skills, beyond the basic level. Of course, this is no guarantee of success in the labour market, but increasingly it seems to be a pre-requisite for at least having a chance of succeeding. For these reasons, it was decided to focus on this basic level of skill acquisition. In particular, the study is an examination of the factors which influence the decision of young people to remain in education beyond the age at which it is compulsory for them to do so, and to acquire a higher level of skills through this education, before entering the labour market. The analysis considers separately 16 year olds, 17 year olds and 18 year olds.

The following section describes previous studies that have investigated such issues. The variables to describe the changing participation levels in post-compulsory education are then outlined, as well as the estimation methodology to be adopted. The results of the analysis are then provided in full, and a final section concludes.

\section{Previous Studies}

Previous attempts to model educational choices in the UK include Pissarides (1981), and Whitfield and Wilson (1991). These two papers differ from each other, in that the earlier paper by Pissarides adopts a straight forward logistic regression, while the latter paper performs a similar logistic transformation, but within the more modern framework of cointegration analysis.

1. In fact, the data used refer to England and Wales. The study does not consider the whole of Great Britain by including Scottish data, because of the different education system in Scotland. For brevity, throughout this study, the term 'England' will be used to refer to 'England and Wales.' 
Whitfield and Wilson also extend the list of explanatory variables used by Pissarides. Pissarides considers real consumption expenditure per capita, earnings of youth workers, starting salaries of graduates, the growth in adult manual earnings, the growth in adult non-manual earnings, the adult unemployment rate and the percentage of new graduates still seeking employment six months after graduation.

The rationale for entering most of these variables should be clear. Per capita consumption expenditure is included to allow for the fact that education is expected to be a consumption-good, and so demand for education should rise as the general level of consumer spending rises. The other variables are included to allow for the investment-good nature of education. Individuals will invest in further education, only if the expected level of future returns outweigh the current costs of making the investment. These returns are captured by Pissarides' earnings variables, which measure the higher starting earnings, and their subsequent higher growth, of graduates/non-manuals, relative to the starting level and growth in average earnings of school leavers/manuals. The wage growth variables are calculated using only two data points in time, being the average annual grow th in earnings between youth earnings and average adult manual earnings, for those who leave school at 16; and the average annual growth in earnings between starting salaries of graduates and average adult non-manual earnings, for those who stay at school beyond the age of 16. Pissarides includes these growth variables, rather than simply using average adult manual and non-manual earnings, because the latter may be strongly correlated with starting wages, leading to problems of multicollinearity. A lower expectation of suffering unemployment is another return to education that may be anticipated by those deciding whether or not to remain at school, and this is allowed for by Pissarides through the inclusion of the two rates of unemployment, for the adult workforce in general and new graduates respectively ${ }^{2}$. It could be argued, however, that representing the returns to those who remain in education beyond the age of 16 by those of graduates, in terms of earnings and unemployment chances, may be misleading, since a considerable number will never attend university, and finish their education at, or even before, the age of 18. As an alternative indicator of the prospects for those who stay on at school, Pissarides therefore calculates an index of relative demand for educated labour. This index is calculated as

$$
\frac{\mathrm{j}{ }_{i} a_{i} N_{i t}}{\mathrm{j}{ }_{i}\left(1 \& a_{i}\right) N_{i t}}
$$

where $a_{i}$ is the proportion of educated labour in sector $i$ in 1971, and $N_{i t}$ is total employment in sector $\mathrm{i}$ in year $\mathrm{t}$. Educated workers are defined to be those with at least one A level, or an equivalent qualification, with the information being taken from the 1971 Census of Population.

The results of the logistic regressions for the period 1955-1978, including all of these variables, are broadly consistent with expectations. Separate equations are estimated for the proportions of boys and girls remaining at school beyond the age of 16. In the boys' equation, the level of per capita consumer expenditure, lagged one year, exerts a strongly significant, positive effect on the decision to remain in education. The estimated elasticity of 2.06 suggests that education is a 'luxury' consumption good. The variables measuring the starting level of earnings

2. Pissarides also enters the rate of unemployment amongst those under 21 years of age, since it may be the immediate difficulty in finding a job which persuades some individuals to stay at school beyond the compulsory leaving age. This variable consistently attracts an insignificant coefficient, however. Similarly, a variable measuring the level of student maintenance grants was included, to capture the costs of continuing education, but was also not found to have an insignificant effect on education choices and so was not reported. 
and their growth all also take their expected signs and attract statistically significant coefficients. The higher is the level of youth earnings, and the higher is their subsequent growth, the less likely are boys to choose to remain at school at the age of 16 , with elasticities of 0.93 and 0.41 respectively. On the other hand, the higher are the starting levels and future growth of earnings received by those who remain at school beyond the age of 16 , the more likely are boys to choose to do likewise, with elasticities of 1.36 for the starting level, and 0.28 for the growth. With respect to the unemployment variables, a higher level of adult unemployment is associated with an increase in the proportion of boys wishing to remain in education, since they will assume that obtaining more education should reduce their chances of being unemployed in the future. The effect, though statistically significant, is not large, however, with an elasticity of 0.21 . The proportion of graduates who are unemployed six months after graduating reduces the desire to remain in education, although this effect is even smaller, and is not statistically significant. Finally, the relative demand for educated workers index, described above, attracts an insignificant coefficient, and so does not seem to have an independent effect on the decision to stay at school, once earnings and unemployment are controlled for.

The estimated equation that explains the education choices of girls differs from its male counterpart in some respects, thus revealing the importance of estimating two separate equations. One of the most obvious differences is that none of the unemployment variables attract significant coefficients, so it does not seem as though 16 year old girls consider that staying on in education will significantly affect their future employment prospects. The demand index does exert a significantly positive effect on girls' educational decisions, however, again contrary to the result obtained for boys. Thus when the relative demand for educated labour is higher, girls are more likely to remain at school beyond the age of sixteen, with an elasticity of 2.41. Of the earnings variables, the one measuring the growth of earnings could not be calculated for girls as it was for boys, since the average adult female non-manual wage is often below the starting wage of female graduates. Pissarides therefore simply includes the average level of adult female non-manual earnings. As in the boys' equation, all earnings variables attract significant coefficients, albeit with lower coefficients than their male equivalents. The starting level and growth in earnings paid to 16 year old leavers reduce the proportion of girls remaining in education beyond 16, with elasticities of 0.31 and 0.18 respectively. The level of graduate starting wages and the level of adult non-manual earnings both influence a greater proportion of girls to continue their education, with estimated elasticities of 0.23 and 0.32 respectively. As with boys, therefore, girls seem to view education as an investment good, investing more when the returns, in terms of higher future earnings are greater, and investing less when the alternative of immediate earnings are more attractive.

As mentioned earlier, the paper by Whitfield and Wilson (1991) differs from the one of Pissarides just described, in that it adopts the cointegration approach, and extends the list of explanatory variables. Their principal reason for doing so is that they show that Pissarides' specification leads to unsatisfactory results when the sample is extended beyond his 1978 finishing date. They therefore include an indicator of changes in the social class structure of the UK population, a variable measuring success rates in GCE examinations, and allow for alternatives to education through a variable measuring the proportion of 16 year old boys or girls participating in youth training schemes (YTS or YOP). The social class variable is defined as the proportion of workers in white-collar jobs. The number of regressors is then reduced, to increase the number of degrees of freedom, by including only one earnings variable, rather than the four employed by Pissarides, and not including his relative demand for educated labour index. The variable adopted is one that measures the rate of return to obtaining a degree, calculated from cross-sectional sources as the improvement in earnings associated with obtaining a degree relative to income 
foregone, net of any student maintenance grant.

The estimation period considered by Whitfield and Wilson is 1956-1985, and separate equations are run for boys and girls. After experimenting with the available explanatory variables, they arrive at a preferred specification for the long-run relationship between these variables and the one measuring the participation in education of 16 year olds, the latter having been logistically transformed. The same specification holds for both boys and girls, and shows that the decision to continue in education beyond the age of 16 is positively related to the rate of return to obtaining a degree, the adult unemployment rate and the proportion of workers in white-collar jobs, and negatively related to the proportion of 16 year olds participating in youth training schemes. Augmented Dickey-Fuller tests on the residuals from both equations suggest that these variables form a cointegrated set for both boys and girls.

Turning to the short-run, dynamic specification, Whitfield and Wilson include an error correction term, as suggested by cointegration theory, but find that an unrestricted Vector Autoregression, whereby lagged levels of the explanatory variables are included rather than the error correction term, performs better than the ECM framework. They therefore begin with a VAR of lag length 3, and then delete insignificant variables until they arrive at their preferred specification. The end product is that all second and third order lags drop out of their equation. The results show that the proportion of sixteen year old boys is significantly increased when the rate of return to obtaining a degree is higher, with an elasticity of around 0.3. The rate of return coefficient in the female equation is, however, smaller, and statistically insignificant. With respect to unemployment, the coefficients on this variable suggest a positive influence on education participation, with an elasticity of around 0.1 in both equations. However, the estimated coefficient only achieves statistical significance in the case of females, contrary to the results of Pissarides, who found that unemployment only affected the education decisions of boys. Of the new variables considered by Whitfield and Wilson, two are found to be relevant, and indeed the social class variable has by far the largest effect of all the variables on the decision to remain in education beyond the age of 16, with an elasticity of around 4 for both boys and girls. The final variable of importance is the one measuring the proportion of sixteen year olds participating in training schemes, with its negative coefficient suggesting that participation in formal education falls as the number involved in training schemes rises. The estimated elasticity is about 0.2 for boys and about 0.4 for girls. The variable measuring success rates in GCE examinations does not appear to have any significant impact on participation rates, in the analysis of Whitfield and Wilson.

These two studies described will form the basis for the current analysis, which is also a time series investigation. Before considering the data to be used, however, a brief summary will be provided of cross-sectional examinations into the decision to remain in education after the period of compulsory schooling has ended. Rather than looking at participation rates, crosssection studies have data at the level of the individual, and so use as a dependent variable a dummy indicating whether or not each individual remains in education after reaching the school leaving age, which can then be explained in terms of the characteristics of those individuals. The disadvantage of cross-sectional data is, of course, that it cannot address changes over time.

In the UK, the best data source for examining participation decisions is the Youth Cohort Study, which has surveyed a succession of cohorts at three points in time each, when the respondents are aged 16-17, 17-18 and 18-19. A number of studies have used the data from various cohorts to examine the factors that influence the decision to participate in post-compulsory education. Gray, Jesson and Tranmer (1993) describe the individual characteristics that have been found to be significant. Females, those whose family belongs to a higher social class and nonwhites are all found to be significantly more likely to continue in education. However, the 
individual characteristic which completely dominates these others is examination success at age 16; the better the individual performs in his or her GCE/GCSE examinations, the more likely he or she is to continue in education. The authors also consider the characteristics of the local labour markets in which the respondents lives. They show that a lot of the difference in participation rates across local labour markets is the result of the characteristics of the individuals who live within them. Over and above this, however, the unemployment rate in a local labour market has a significant influence on the participation rate. This effect is actually negative, implying that individuals are less likely to remain in education in areas with high unemployment. It seems likely that this variable is picking up the effects of more general social conditions in local labour markets, rather than saying that high local unemployment itself influences young people to leave school.

Further studies have developed some of these findings. Ashford, Gray and Tranmer (1993) examine whether the introduction of the GCSE examination could explain the large increase in participation that occurred in the late 1980s in the UK. They find that the new system did lead to an increase in the proportion of candidates obtaining good grades, which in turn leads to an increase in the probability of continuing education, as described in the previous paragraph. This was not the only cause of the increase in participation, however, since the authors point out that there was also an increase within all qualification groups.

Cheng (1995) considers the influence of school characteristics on the decision to remain in education after reaching the school leaving age. He finds that the propensity to stay on is higher among students who have attended voluntary aided, rather than Local Education Authority maintained, schools. The size of the school's sixth form (positively), and the degree of teacher turnover and the proportion of students taking free meals (both negatively) all also have a significant impact on a school's post-compulsory participation rate.

Finally, a study by Gray, Jesson and Tranmer (1994) further examines the effects of local labour market characteristics. They confirm the earlier result that participation rates are lower where unemployment is higher, and then show that the proportion of long-term unemployed in a local labour market has a negative effect on staying-on rates, while the percentage change in unemployment has a positive effect. These effects are statistically significant in only one of the three cohorts that they consider, however. The authors also allow for other characteristics of local labour markets, such as the industrial structure, but again find only weak effects. They conclude that local labour market conditions do explain some of the variation in participation rates across such areas, but that they explain less than the characteristics of the individuals who live there, and their influence seems to be declining over time. 


\section{The Data}

The dependent variable in the following analyses is the proportion of the relevant age group who remain in full-time education, that is within a recognised educational establishment such as a school or college of further education ${ }^{3}$. It was decided to include apprenticeships as part of fulltime education in Germany, because of the important role played by such vocational training in the educational system of that country. Such apprenticeships are very different to, for example, the Youth Training Scheme in England, which is why the number of places on this scheme is used as an explanatory variable in England, while the number participating in apprenticeships in Germany is counted as part of the dependent variable ${ }^{4}$. The relevant age group was defined according to age on 1 September, that is at the beginning of the school year. Three age groups were considered: 16 year olds, 17 year olds and 18 year olds. As many data points as possible were collected in each country, from 1960 to the present day. The actual samples used were 1970-1992 in Germany, 1969-1992 in the Netherlands, 1970-1994 in Sweden, and 1961-1994 in England.

Figure 1 plots the rate of participation in education amongst 16 year olds for each of the four countries being considered, separately for a) females and b) males. Figures 2 and 3 repeat the graphs for 17 year olds and 18 year olds respectively.

Figure 1 reveals that consistently over $90 \%$ of 16 year old Germans have remained in fulltime education throughout the period for which data are available. The other 3 countries have seen their participation rates rise over the period, with similar patterns for both males and females. By the 1990s, both the Netherlands and Sweden had matched the German 16 year old participation rate, most of the increase in the Netherlands coming in the late 1960s and early to mid 1970s, while Sweden has seen two periods of faster growth, in the late 1970s and the early 1990s. The period of most rapid increase in England was in the late 1980s and early 1990s, although the participation rate there was still some 20 percentage points lower than in the other three countries, with the slight fall in the rate in 1994 suggesting that the English 16 year old participation rate may have peaked at this level.

Participation rates for 17 year olds are graphed in Figure 2. The pictures are similar in relative terms to those for 16 year olds, although all rates are, as expected, slightly lower than their 16 year old counterparts. One peculiar aspect of the data is the large fall in German 17 year old participation rates in 1976 and 1977. In the absence of a reasonable explanation for this fall, it would seem that there are problems with the data in these two years ${ }^{5}$. Otherwise, the German rate has trended very slightly upwards, but in general fluctuating around $85 \%$. Again, the Netherlands and Sweden have been catching up, with Swedish rates equalling those in Germany by the end of the period. The Swedish 17 year old participation rate increased at its fastest rate during the mid 1970s, with the period of fastest growth in the Netherlands being slightly earlier. Again England has trailed the other three countries throughout the period, with rates just reaching $60 \%$ for 17 year old females by 1993, immediately following the period of fastest growth in the English rate.

Finally turning to the participation rates of 18 year olds, for which there is no Swedish

3. Exact definitions of all variables used, together with sources, are provided in an appendix.

4. In fact there is a similar scheme to the Youth Training Scheme in Germany, but data on participation could not be obtained, as so this was not included amongst the explanatory variables in the equations for that country.

5. In an attempt to control for this problem, a dummy variable with the value of one was included in the German equations. While the coefficient on this dummy variable was negative and statistically significant, as the graphs would suggest, its inclusion did not affect the other estimated coefficients in any substantial way, so that this data problem does not seem to have influenced the results. 
data, Figure 3 reveals a slightly different pattern. Ignoring the fall in German rates in 1976 and 1977 again, rates for all three countries have trended upwards throughout the period, with Germany always having the highest proportion of its 18 year olds still in full-time education. In this case, there is no evidence of the Netherlands narrowing the gap on Germany, the female Dutch rate reaching $67 \%$ by the end of the period, compared to $84 \%$ in Germany. England again has consistently the lowest rate, with the usual more rapid increase coming towards the end of the period, so that by $199338 \%$ of 18 year old females in England were in full-time education.

Turning now to the explanatory variables, these were chosen to reflect the time series studies described above. There follows a description of all of the variables for which an attempt was made to find data, although not all of the data series could be obtained in all of the countries. Where possible, separate data series were collected for males and females.

The Whitfield and Wilson (1991) approach of only including one earnings variable was adopted here, in order to protect degrees of freedom, given the expanded set of variables used, relative to Pissarides' (1981) specification. The idea behind the use of this variable is that it measures the rewards that can be gained by those offering higher levels of education relative to the rewards on offer for leaving school immediately. In each country except the Netherlands, a separate variable was derived for males and females. For Germany, the variable used measured the ratio of the earnings of those in technical jobs (kaufmannische und technische), to those in manual work (Arbeiter). In the Netherlands, the ratio of the annual earnings of persons at education level 5-7 relative to education level 3 was used. Swedish data could only be obtained for specific industrial groups. The mining, quarrying and manufacturing group (SNI 2+3) was chosen as it covered a relatively large section of the workforce. For males, the variable used was the ratio of 'management personnel' earnings to the earnings of 'personnel with routine work.' For females, the small numbers in the former category made a similarly defined variable unreliable, so that the ratio of 'personnel in responsible positions with qualified work' earnings to 'personnel with routine work' earnings was used. In England, the variable used measured the ratio of professional to manual earnings.

As in both previous time series studies described, a youth unemployment variable was included. It was decided to include the rate of unemployment among young men and women, defined separately in each country, since it is the youth labour market which school leavers must face if they decide not to continue their education ${ }^{6}$. In Germany, the unemployment rate amongst 20-24 year olds was used. The age groups adopted in the other 3 countries were 15-24 year olds in the Netherlands, 16-19 year olds in Sweden, and 18-20 year olds in England. The choice of these age groups was determined by the available data. A series could not always be defined for those of school leaving age, for various reasons, for example in England 16 year olds have not been included in official unemployment statistics since 1988, because of their ineligibility for benefits. It seems reasonable to assume, however, that in this case the unemployment rate amongst 18-20 year olds will offer a reasonable description of the labour market facing 16 year old school leavers ${ }^{7}$.

6. Against the use of this variable, it could be argued that the youth unemployment rate does not accurately measure labour market tightness facing young people, because of the existence of training schemes in all four countries that take such young people out of the unemployment count. However, when the adult unemployment rate was substituted for the youth unemployment rate, the results were largely unchanged.

7. Note that the use of these varying age groups for defining the unemployment rate avoids this explanatory variable being jointly determined along with the dependent variable. If the unemployment rate was defined for exactly the same age group as the participation rate, the two would be linked via the equation unemployment rate $=$ employment rate - education participation rate - other inactive rate. 
Despite Whitfield and Wilson not finding any effect for a variable measuring examination results at age 16, it was decided to include a variable that measured in some way success in the education system prior to the post-compulsory participation decision, since the cross-sectional examinations of the Youth Cohort Study in the UK have suggested that such an effect may be important, as described above. This variable was obviously the most difficult to measure in any consistent way across the four countries, because of the different natures of their education systems. No relevant measure could be obtained at all for the Netherlands. In Germany, the proportion of the relevant cohort achieving mittlere Reife was used. This variable measured the percentage of the age cohort who had obtained Realschulabschluss or who had proceeded successfully to the Abitur from a Gymnasien. For Sweden, a variable was derived which measured the percentage of the total number of students who registered for an academic course in English in grade 9. Grade 9 is the final year of compulsory schooling in comprehensive schools in Sweden, while the academic course is taken, as opposed to a general course, by the better students. The variable is therefore intended to measure the proportion of the cohort who are considered to be more able, in the final year of compulsory schooling. For England, the variable used measured the proportion of the 16 year old age group achieving at least 5 GCSEs at grade $\mathrm{C}$ or above, or the equivalent of this (for example, 5 or more O-level passes in the pre-GCSE period). These series could be identified separately for males and females in each of the three countries. In order for the correct cohort to be identified in each equation, this variable was lagged where appropriate. For example, when considering the participation rates of 17 year olds, the 'education success' variable was lagged by one year, so that the success rate of the 17 year old cohort under consideration was being used.

Both of the time series studies described above attempted to allow for the consumptiongood nature of education, by including some measure of consumption expenditure. A measure of real per capita consumers' expenditure was obtained for the Netherlands, Sweden and England. A measure could not be found for Germany. It is expected that as consumers become increasingly well-off, on average, they will 'spend' more on education, by foregoing income to remain at school or college.

Alternative options facing those deciding whether or not to leave school were captured by the proportions participating in youth training schemes. Such data could only be obtained for two of the countries under consideration. In Sweden, a variable measuring the proportion of 16-19 year olds participating in 'Labour Market Training' was used. The available data could not be disaggregated by sex. In England, the proportion of 16 year olds participating in government training schemes was used. In this case, separate series were defined for males and females.

The final variable used was a dummy variable, defined only in England, to allow for any possible effects on participation of the raising of the school leaving age from 15 to 16 in 1973.

Having described the variables to be used in this study, the next section moves on to outline the method of analysis to be adopted. 


\section{Estimation}

This investigation will follow much recent work in the field of econometric time series analysis by examining the data within a cointegration framework. This involves an initial exploration of each data series, to establish whether the variables in the analysis are stationary series or not. It has been shown, first by Granger and Newbold (1974), that if the series are non-stationary, then inferences can be seriously flawed, with relationships being claimed that are in fact completely spurious. The results below reveal that, with two exceptions, all the variables in all the countries described above are in fact non-stationary. The variables must therefore be transformed into stationary series, before they can be analysed. This can be achieved by first-differencing the variables when they are integrated of order 1 . However, if only first differenced variables were to be analysed, the results would say nothing about their long-run inter-relationships. Because of this, a two-step estimation procedure, as suggested by Engle and Granger (1987), is followed. The first step involves performing an OLS regression between the variables of interest, to provide information on the long-run relationships between those variables. It is then necessary to test whether the variables form a cointegrated set, which involves examining whether they move together over time in a certain way, so that a particular linear combination of them forms a stationary series. The coefficients from the OLS regression can be taken as the weights for this linear combination, normalised so that the dependent variable in the OLS regression receives a weight of unity. Thus, a linear combination can be represented by the residuals from the first stage regression. If these residuals are found to be stationary they can be entered, as an error correction term, into an equation of first differenced variables. The latter regression will therefore only contain stationary series, so that the usual inference techniques will be valid. Thus the first stage regression informs the researcher as to how the variables move together over time, assuming that they do form a cointegrated set, while the second stage equation describes how short-run deviations of the explanatory variables from their long-run trend influence deviations in the dependent variable from its long-run trend.

The equations are actually estimated by performing a logistic transformation. The reason for this is to ensure that the predicted values for the dependent variable lie in the $0-1$ interval for all combinations of the explanatory variables, which is appropriate when the dependent variable is a proportion. This transformation requires writing the proportion who remain at school beyond the minimum leaving age, $\mathrm{P}$, in terms of the vector of explanatory variables, $\mathrm{X}$, as:

$$
P^{\prime} \frac{e^{\beta \log X \%}}{1 \% e^{\beta \log X \%}}
$$

Re-arranging gives

$$
\frac{P}{1 \& P}{ }^{\prime} e^{\beta \log X \%}
$$

Taking $\operatorname{logs}$ on each side of this equation

$$
\log \left(\frac{P}{1 \& P}\right)^{\prime} \beta \log X \% \mathrm{e}
$$


Therefore, logarithmic equations were estimated by transforming the proportion in education variable, $\mathrm{P}$, into the dependent variable, $\log (\mathrm{P} / 1-\mathrm{P})$, and regressing this against the logs of all of the explanatory variables described above ${ }^{8}$.

The drawback with this approach is that the coefficients do not automatically represent elasticities, because the dependent variable is the log of P/1-P, rather than simply log P. To get elasticities for the proportion continuing in education, rather than for the $\mathrm{P} / 1-\mathrm{P}$ variable, it is necessary to multiply the latter elasticity by (1-P). Hence, the elasticity of the proportion of a particular cohort remaining at school, with respect to a variable $X_{i}$, is given by

$$
\frac{\mathrm{MP}}{\mathrm{M}_{i}} \frac{X_{i}}{P} \quad(1 \& P) B_{i}
$$

where $\beta_{\mathrm{i}}$ is the estimated coefficient on the variable $X_{\mathrm{i}}$ when equation 1 is estimated. Since this elasticity varies as $\mathrm{P}$ varies, all elasticities reported below will be calculated according to equation 2 using the mean value of the relevant dependent variable ${ }^{9}$.

\section{Results}

\section{i) Order of Integration of Variables}

The first task is to check the order of integration of each of the variables under consideration. This was done, for each series $Z_{t}$, by estimating augmented Dickey-Fuller equations of the form:

$$
? Z_{t}^{\prime} \quad \text { a } \% ß t \% \mathrm{f} Z_{t \& 1} \% ?_{1}\left(Z_{t \varangle 1} \& Z_{t \varangle 2}\right) \% ?_{2}\left(Z_{t \varangle 2} \& Z_{t \& \beta}\right) \% \ldots \% ?_{r}\left(Z_{t \varangle r} \& Z_{t \varangle r \& 1}\right) \% \mathrm{e}_{t}
$$

The number, $r$, of lagged differences included was set as the number necessary to eliminate serial correlation in the disturbance term, $e_{t}$, according to a Lagrange Multiplier test. A test of the null hypothesis of the existence of a unit root, that is whether the series, $Z_{4}$, is non-stationary, then involves calculating the augmented Dickey-Fuller (ADF) statistic, a t-type-statistic, for the coefficient $f$ on the lagged level term. Since the distribution of this statistic is non-standard under the null hypothesis that the series is non-stationary, the calculated statistic must be compared to the critical values originally supplied by Dickey and Fuller ${ }^{10}$. This is done in Tables 1 to 4 , for

8. In the English equations, two of the explanatory variables, the proportion of sixteen year olds involved in youth training schemes and the dummy for the raising of the school leaving age, both take the value of zero in a significant number of the years. Since the log of zero cannot be calculated, these two variables were entered in linear form.

9. For the two variables entered in linear form into the English equations (see footnote 3), the elasticity of the participation rate with respect to one of these variables, $X_{i}$, is given by $X_{i} \cdot(1-P) \cdot \beta_{i}$, where the mean value of $X_{i}$ is used, as well as the mean value of $\mathrm{P}$, in the calculation.

10. Note, however, that standard normal critical values can be used, if the true data generating process contains a time trend, as described in Dickey and Fuller (1981). Therefore, in the cases where the t-statistic was not large enough to reject the null hypothesis of a unit root using Dickey and Fuller's non-standard critical values, but was large enough to reject the null using standard normal tables, then a likelihood ratio test of the joint significance 
each of the variables under consideration, in each of the four countries. Similar equations are then estimated for the first differences of all variables, with the test statistics also reported in Tables 1 to 4 .

The results reveal that the null hypothesis of a unit root cannot be rejected in the levels of any variables under consideration, with the exception of the earnings ratio variable in the Netherlands and the female 'prior education success' variable in Sweden. Therefore, all variables bar these two are non-stationary, and so a straightforward OLS analysis would lead to incorrect inferences concerning the significance of the explanatory variables, as described above. Accordingly, an Engle and Granger (1987) two-step procedure is estimated. Properly speaking, the two variables noted that appear to be stationary should not be included in the analysis with the others. However, in the interests of trying to maintain comparability across countries, they continued to be included ${ }^{11}$.

Considering the ADF tests on the first differences of all the variables, in the majority of cases, the null hypothesis of a unit root can be rejected, suggesting that these variables are difference-stationary, or integrated of order $1, \mathrm{I}(1)$. There are a number of exceptions in all countries, however, where the null hypothesis of a unit root in the first difference cannot be rejected. Taken at face value, such results suggest that such variables will grow at a constantly increasing rate, which seems implausible for 'proportion' variables such as participation rates and unemployment rates. These results may well be the outcome of the well-documented low power of ADF tests to reject null hypotheses of unit roots. Since all the test statistics in question are close to the rejection values, the analysis will proceed as if all variables are I(1), as described below.

\section{ii) Long-Run Results}

The results obtained when equation 1, above, is estimated by OLS are provided in Tables 5 to 8 . As mentioned, any inferences based on these equations will be incorrect, because of the nonstationarity of the variables, and so no standard errors are provided. Elasticities, calculated according to equation 2 at the mean values of the appropriate variables are provided in parentheses. The results will be considered for each country in turn.

Figures 1 and 2 revealed that, in Germany, participation rates of 16 and 17 year olds have been fairly constant, at a high level, throughout the period under consideration, thus leaving little for the explanatory variables to explain. The rather high coefficients reported in the 16 and 17 year old equations in Table 5, particularly on the earnings variable, and the high standard errors, not reported for the reason given in the previous paragraph, are both suggestive of the instability of the parameter estimates. It therefore seems logical to focus on the 18 year old equations in the German case, where there has been significant changes in participation over time. The variable which has had most influence in this rise in participation among German females has been the education success variable. On average over the period, a $1 \%$ rise in the proportion achieving mittlere Reife at age 16 has been associated with a $0.8 \%$ rise in the education participation of 18 year old women. The earnings variable also takes its anticipated positive effect, although with a

of the time trend and the lagged level term was performed, using the critical values contained in Dickey and Fuller (1981). If this null hypothesis was rejected, then there was no evidence for a unit root in the series, and is indicated by $\mathrm{a} \neq$ in the tables.

11. In fact, when the Dutch and Swedish equations were re-estimated with these variables omitted, the results on the other variables were unaltered. 
smaller effect, a $0.5 \%$ rise in participation resulting from a $1 \%$ rise in the ratio of 'technical' to manual earnings. The unemployment coefficient surprisingly suggests that participation falls as youth unemployment rises, although the implied elasticity is tiny. A similar negative but very small unemployment effect is found in the male equation. The relative importance of the other two variables is reversed for males, however, with the estimated earnings ratio and education success elasticities being 1.34 and 0.48 , respectively.

In the Netherlands, the role of the rising level of income available over time, as measured by per capita consumer expenditure, seems to be of prime importance in explaining the rise in education participation, as individuals 'spend' some of this income on education. A $1 \%$ rise in per capita consumer expenditure is associated with a $0.64 \%$ rise in the participation of 16 year old women, a $1 \%$ rise in the participation of 17 year old women, and a $1.5 \%$ rise in the participation of 18 year old women. The equivalent male elasticities are approximately half these female estimates in each case, although such numbers are nevertheless still quite large. The estimated unemployment elasticities are uniformly positive, but are all very small. The largest elasticity suggests that a $1 \%$ rise in youth unemployment is associated with a $0.13 \%$ rise in the participation rate of 17 year old women. The other five unemployment elasticities are all less than 0.1. This leaves the earnings elasticities, which are surprisingly negative, as well as being large in absolute size, particularly for 18 year old women, but also for 18 year old men and 17 year old women. Examining the raw data reveals a definite downward trend in the ratio of education level 5-7 to education level 3 earnings, from 1.88 in 1969 to 1.52 in 1992. It would therefore appear that these results reflect the relative movements of the earnings and participation variables, without implying any causation between them.

Swedish women are particularly influenced by their prior success when deciding whether to continue their education. The elasticities are large, 1.25 and 1.97 for 16 year olds and 17 year olds respectively, and dominate the other female coefficients in Table 7, with the exception of the expenditure elasticity of 1.14 in the 16 year old equation. Swedish men seem much less influenced by their prior attainment, the estimated coefficients suggesting that a $1 \%$ rise in the proportion of males in grade 9 attending academic English courses is associated with a $0.56 \%$ rise in the participation of 16 year olds, and a $0.24 \%$ rise in the participation of 17 year olds. For men, the dominant explanatory variable is clearly the expenditure variable. Over the period, a $1 \%$ rise in per capita consumer expenditure is associated with a $1.33 \%$ rise and a $1.14 \%$ rise in the participation rates of 16 year old and 17 year old men, respectively. The remaining variables in the Swedish equations all have smaller effects. The highest elasticities to be found on the youth unemployment variable so far in this analysis are found in the Swedish 16 year old equations, but these are still only 0.2 for women and 0.16 for men. The 17 year old unemployment elasticities are tiny. The elasticity on the earnings ratio variable is 0.39 in the male 16 year old equation, and, surprisingly, -0.48 in the female 17 year old equation, the remaining two earnings effects being smaller in absolute value. Finally, the proportions of young people involved in labour market training takes a positive coefficient in all four equations, suggesting that training is not a substitute for education, although the estimated effects are all very small indeed.

Finally, the long-run results for England are presented in Table 8. British women follow their German and Swedish counterparts in being most influenced by prior attainment when making their post-compulsory participation decision. The elasticities increase with the age of the cohort, a $1 \%$ rise in the proportion of a cohort achieving 5 or more grade A-C GCSEs, or equivalent, being associated with increases in participation rates of $1.08 \%$ for 16 year olds, $1.1 \%$ for 17 year olds and $1.53 \%$ for 18 year olds. It should be noted that the rise in per capita consumer expenditure has also been an important determinant of the increasing participation of 18 year old women, with an elasticity of 1.54 . For men, success in compulsory schooling has also been a key 
factor in the decision to remain in education beyond the state leaving age, with the estimated elasticity being just under 1 in the 16 and 17 year old equations, and just under 2 in the 18 year old equation. This effect is dominated in the former two equations, however, by the influence of the rise in professional earnings relative to manual earnings. The estimated coefficients suggest that a $1 \%$ rise in this earnings ratio is associated with a $1.18 \%$ rise in the participation rate of 16 year old men, and a $1.22 \%$ rise in the participation rate of 17 year old men. The earnings elasticity remains a respectable 0.7 in the 18 year old equation, although it is clearly dominated now by the GCSE effect. The remaining coefficients in Table 8 all imply much smaller elasticities. Men seem to be less influenced by the level of per capita consumer expenditure than women, while women seem less influenced by the relative size of professional earnings than men (the 18 year old female earnings coefficient actually being negative). In line with the other countries, the estimated unemployment elasticities are all small. This is particularly the case in the male equations, the female elasticities being slightly higher at around 0.1 for 16 and 17 year olds and around 0.2 for 18 year old. Finally, unlike in Sweden, the training variable takes conflicting signs in different equations, although as in Sweden, the estimated effects are all tiny.

\section{iii) Interpretations}

How can these results be interpreted? The key variable that seems to explain participation in postcompulsory education seems to be prior success in the education system. This is the case particularly for women. There are several possible interpretations of this result, mainly connected with the idea of a threshold achievement level, beyond which individuals choose to continue their education. The higher the proportion of the cohort achieving this threshold, the higher the rate of participation in post-compulsory education. The different interpretations hinge on why such a threshold should exist. One possibility is that it is a formal requirement laid down by educational authorities, that a certain standard must be reached before further study is allowed. A second is that the threshold is not a formal one, but exists more in the minds of the young people, the idea being that prior success in the educational system convinces them of their ability to obtain further success if they were to continue their educational careers beyond the age of compulsory schooling. Anecdotal evidence seems to prefer the latter interpretation. In particular, in none of the four countries are there formal standards that have to be attained before further education is allowed. While it may be the case that some courses of post-compulsory study have certain entrance requirements in terms of prior educational success, there are courses that can be followed in each country that do not have such entrance restrictions. For example, it is true that, in England, a lot of the increase in participation in post-compulsory education is accounted for by A-level study, for which certain standards are required, but it is also true that there has been an increase in enrolment in further education colleges, where good GCSE results are not a pre-requisite for entry. In Germany, if the 'improved aspirations' effect is the dominant explanation of the positive correlation between post-compulsory participation and mittlere Reife achievement, then it is likely that we would observe more young people continuing in the academic stream. On the other hand, if most of the increased numbers in post-compulsory education were to be found in the vocational apprenticeships, then an alternative explanation may be appropriate. Apprenticeships in Germany typically last for three years. If an increasing number of participants are only starting their apprenticeships after leaving a Gymnasien with mittlere Reife at age 16, then they will still be participating when they are 18, and so we will observe both a rise in the proportion of 16 year olds achieving mittlere Reife, and a rise in education participation amongst 18 year olds two years later, therefore offering an explanation for the observed positive correlation between these two variables. In fact, examining data from the period 1985-1992 only, it appears that participation 
in both academic and vocational courses has increased amongst 18-19 year olds, and so both of the above explanations of the observed results could be valid. Differentiating by gender, almost all of the increase in participation amongst 18-19 year old women in this period has been in academic courses. This may partly be the reason why the mittlere Reife result is stronger in the female equation than in the male.

An alternative explanation of the positive correlation between participation and 'prior success' is that the latter is endogenously determined, and should not be treated as an exogenous explanatory variable. For example, if individuals decide at, say, age 14 or 15 that they want to participate in post-compulsory education, then they may put more effort into their current studies and achieve a higher level of success in compulsory education. Under this interpretation, it would then in effect be the higher participation rate 'causing' a higher prior success rate. Against this line of argument, it can be pointed out, as above, that prior success is not necessary for postcompulsory study in any of the four countries, and so such application to compulsory-level studies is not absolutely necessary, although of course it may be necessary for particular courses that individuals wish to pursue. In the absence of reasonable measures of innate ability amongst cohorts of individuals, there does not seem any way to show that the 'proof of ability' interpretation offered above is a more accurate description of the mechanisms at work than the reverse causality argument offered in this paragraph.

The results for the other variables in the estimated equations are more straightforward to interpret. The discussion in the data section above described the motivation for the inclusion of the wage ratio variable. The generally positive coefficients on this variable support the intuition offered, that the higher the inequality of earnings across skill levels, the greater the motivation to remain in education and become highly skilled. This variable seems to be more important in explaining the participation decisions of males than females. It may be that males see the potential rewards to skill acquisition clearly, and are strongly motivated by them. For example, it has been suggested that in Sweden a high proportion of women work in the public sector, while a high proportion of men work in the private sector, where the returns are higher ${ }^{12}$. There is therefore more incentive for males to acquire more education. It is probably also the case that labour market discrimination affects the rewards on offer to females, and so blurs such incentives for women. If young women therefore feel a greater need to prove their ability through qualifications before they can obtain such rewards, then this may also explain why the 'prior success' variables seemed to be more important in the female equations than in their male equivalents.

Similarly with the other 'financial' variable, the results support the hypothesis that as per capita income levels rise, some of this extra income is 'spent' on education. Again, this effect seems to have more influence on the participation of males rather than females. Perhaps the families who are using their higher income levels to persuade their children to remain in education are more likely to push their sons rather than their daughters into post-compulsory participation.

The youth unemployment variable has been shown to have a consistently small estimated elasticity in all of the equations ${ }^{13}$. This would seem to suggest that if youth unemployment was to

12. Although this study is focussing on the first years of post-compulsory education, rather than university-level education, it has also been pointed out that wage differentials could be the reason for lower university enrolments rates in Sweden, with the relatively low wage inequality in that country reducing the returns on offer for acquiring a university education, and so reducing the incentive to continue studying to that level.

13. It has been pointed out that although the estimated elasticities are small, unemployment can still have large effect on observed participation rates, since it is starting from a low base. Thus, a doubling of unemployment rates, that is a $100 \%$ increase, could occur over the space of a few years, causing a $10 \%$ increase in participation, on the basis of an elasticity of 0.1 . It should be noted, however, that 'success rates' have also varied by large 
be reduced, this would not have very serious effects on education participation rates, and skill targets could still be pursued. The most plausible reason for this result is that those who leave school at the end of compulsory schooling are the ones that are likely to leave school anyway, regardless of the state of the labour market, possibly for lack of ability or motivational reasons. This result is consistent with the findings of Rudd (1997), whose interviews with young people in education in England reveal little fear of unemployment, most being confident of finding work despite an awareness of the general level of unemployment. In Sweden, it has been suggested that the provision of schemes for the young unemployed, as well as generous labour market insurance, reduce the threat of unemployment. It would seem that the threat of unemployment does not have a large influence on the decisions of young people.

Similar reasoning can be attached to the training variable. In the two countries for which data is available, no effect of training places on education participation rates is observed. It seems plausible that places on training schemes are taken up by those most likely to leave full-time education anyway, and that individuals do not deliberately end their schooling, to obtain a place on a training scheme. It would seem that training schemes could be safely expanded, without harming participation in full-time education to any great extent.

\section{iv) Cointegration Tests}

Turning now to the tests for cointegration between the variables in each equation, these are provided by the augmented Dickey-Fuller (ADF) statistics at the foot of each column in Tables 5 to 8 . The test is a test of the stationarity of the residuals from each regression, performed in exactly the same way as the augmented Dickey-Fuller tests above. The null hypothesis of a unit root in the residual series can be rejected in the majority of cases, although there are a few exceptions. Germany, where attention is being focussed only on the 18 year old equations, and the Netherlands, apart from the 18 year old female equation, have satisfactory results, while in England, the null hypothesis of a unit root in the residuals can be rejected in all but both of the 18 year old equations. The largest problems are associated with the Swedish results, where the null of a unit root can be rejected in only one instance.

The residuals, $e_{t}$, can be written as

$$
e_{t}{ }^{\prime} P_{t} \& b X_{t}
$$

where $b$ represents the estimated coefficients in the OLS regressions of $P_{t}$ against the vector of explanatory variables $X_{t}$, as reported in the various columns of Tables 5 to 8 . In the cases where a unit root can be rejected in the residuals, so that the residuals are shown to be stationary, this means the right-hand side of equation 4 is also stationary. Hence, the linear combination of all the explanatory variables that puts a weight of unity on the dependent variable, $\mathrm{P}_{t}$, and the appropriate estimated coefficient, $b$, on each of the explanatory variables, is a stationary series. Therefore, the variables under consideration can be said to form a cointegrated set: they do move together over time.

\section{v) Short-Run Results}

amounts, and have more than doubled in the sample period in Germany and England, and so the conclusion remains that this variable has the largest effect. It is fair to say, though, that wage ratios have not varied by more than about $40 \%$ in any country over the sample period. 
The next stage, as advocated by Engle and Granger (1987) and described above, was to estimate dynamic equations with all the variables first differenced. The residuals, lagged once, from the cointegrating regression were also included, to provide long-run information based on the levels of the variables. Finally, a lagged dependent variable was included in each equation. In the cases where the explanatory variables were integrated of order 1 , so that their first differences were stationary, and the residuals from the cointegration equation were $\mathrm{I}(0)$, then all included variables were therefore stationary, and so normal inferences as to their significance will be valid. However, it has been noted above that the null hypothesis of a unit root could not be rejected both in some of the first differenced data series, and in some of the residuals from the cointegrating equations. In attempting to achieve some consistency across countries, age groups and genders, the short-run equations in these cases were estimated in the same way as described above, but it should be borne in mind when considering the results that the possible presence of $\mathrm{I}(1)$ variables in these equations will render statistical inferences suspect. The results are provided in Tables 9 to 12 . The coefficients reveal how deviations in the variables from their long-run path influence short-run deviation in the participation rate from its own long-run path. In each case, if serial correlation was detected in the residuals using a Lagrange Multiplier test, then the Cochrane-Orcutt correction was performed in an attempt to remove such a problem.

Considering first the results for Germany in Table 9, it can be seen that the lagged residuals from the equivalent long-run cointegrating equation, the 'error correction mechanism,' attracts a statistically significant coefficient in each equation. The error correction mechanism is in effect measuring the extent to which participation is above its long-run trend value, given the values of the explanatory variables. The negative sign is thus theoretically consistent, suggesting that participation will fall towards its long-run trend value when it is running above this value in the period before, and vice versa.

As noted above, the 18 year old equations are the most reliable in the case of Germany. Considering the relevant columns, it can be seen that, apart from the error correction term and the lagged dependent variable, the only variable to attract a statistically significant coefficient, in both the female and the male equation, is the variable measuring prior attainment in the education system. Thus the key variable in explaining deviations in the proportion of young Germans remaining in education seems to be how successful they have been earlier in their academic careers. The coefficients on the earnings ratio variable are actually larger than the mittlere Reife coefficients in both equations, although the large standard errors on the former make them unreliable and, in fact, statistically insignificant. The youth unemployment coefficients are similarly insignificant, with t-ratios of less than 1.

Turning to the Netherlands, there appear to be few variables that can explain short-run deviations in the participation rates of women, apart from the error correction and lagged dependent variable effects. Only two other significant coefficients are to be found in the three female equations. In the 17 year old equation, the youth unemployment variable attracts a small, but nevertheless statistically significant, coefficient. The other variable to have a statistically significant effect is the one measuring the earnings ratio, although the coefficient is negative, contrary to the predicted effect. The likely reason for this odd result was discussed above in the context of the Dutch long-run equations. The male equations are somewhat more successful in explaining short-run deviations in participation rates than their female equivalents in the Netherlands. The youth unemployment coefficient is strongly significant in both the 16 and the 17 year old equations, although in economic terms the magnitude of the effect remains small. A much larger, positive and statistically significant coefficient is obtained on the earnings variable in the 16 year old male equation. It would seem that 16 year old Dutch men are tempted by the promise of future returns to remain in education. The coefficient in the 18 year old equation reverts to 
being negative, and statistically significant, however. The final significant effect in the Dutch equations is also found in the 18 year male equation; changes in per capita consumer expenditure having a large effect, strongly significant in statistical terms, on short-run deviations in the education participation rate.

The Swedish equations perform least well in terms of offering consistent results across the various age groups and genders. With the exception of the error correction term, none of the variables take coefficients of consistently the same sign in all four estimated equations. A further problem with the 17 year old male equation, is that serial correlation remains in the residuals, even after performing the Cochrane-Orcutt correction. A possible reason for these problems is that, as noted above, the variables only seemed to form a cointegrated set in one instance, the 16 year old male equation, so that the short-run equations may be misspecified as error correction equations, causing the erratic results. Unfortunately, if the 16 year old male equation is to be viewed as the best specified, no variables in that equation attract statistically significant coefficients. Briefly considering the significant coefficients found in the other three equations, the unemployment variable has just such a significant effect in the 16 year old female and 17 year old male equations. The coefficients are both positive, and both large relative to unemployment effects obtained in other countries, but still smaller than the coefficients on other variables. The earnings ratio appears with a significant coefficient once, in the 17 year old female equation, that is both large and takes the anticipated positive sign. The proportion involved in youth training attracts its only significant coefficient in the whole analysis in the 17 year old male equation, the coefficient taking the anticipated negative sign. On this basis of this one coefficient at least, it can be suggested that young people will be more tempted to leave school if there are good training opportunities awaiting them. Finally, the variable measuring the proportion of $9^{\text {th }}$ grade students taking an academic course in English epitomises the inconsistency in the Swedish results, by taking a significantly negative coefficient in the 16 year old female equation and a significantly positive coefficient in the 17 year old female equation. Both coefficients are large in absolute size, although it is difficult to offer any interpretation when the results vary so much across equations.

The final results are contained in Table 12, for England. The short-run coefficients are very similar, in terms of their relative size, to their long equivalents. The female equations are dominated by the GCSE variable measuring prior attainment in the education system. This variable attracts large, positive, statistically significant coefficient in all three female equations. Per capita consumer expenditure surprisingly attracts a significantly negative coefficient in the 18 year old female equation. The remaining significant coefficient in the female equations is on the dummy variable controlling for the raising of the school leaving age in 1973. The negative coefficient implies that participation of 18 year olds fell in the year that this policy change occurred, although it is difficult to think of a particular mechanism at work here. Turning to the male equations, the same result found in the long-run equations emerges, that for males the earnings ratio becomes the dominant variable. The coefficient on the variable measuring the ratio of professional to manual earnings attracts a significant coefficient in all three male equations, that is positive in sign and large in size in each case. The 'GCSE effect' remains important, however, particularly for 16 year old men, where a statistically significant coefficient is found.

\section{Conclusion}

This conclusion will attempt to draw together the results presented above. First, however, the problems with the analysis should be highlighted, to put this discussion into context. As with most international studies, the key problem is one of comparability. First, there is the data. The 
variables are defined differently in each country, so that comparison of the relative sizes of the estimated elasticities is not strictly valid. This is most obvious with respect to the 'education success' variable, where the different education systems in each country necessitated a very different measure of the prior success of the cohorts in education. There are similar, if less dramatic, problems in measuring the other variables in the analysis. For example, different occupational groups are used to provide the earnings ratio variable in each country, while different age groups are used for the youth unemployment variable. The second issue relates to the estimation method. If only one equation were being estimated, then a much fuller statistical analysis could have been undertaken, further investigating the properties of each time series and the dynamic properties of the estimated equation. However, 24 equations were estimated in this study ( 3 age groups $x 2$ genders $x 4$ countries), and a standard approach had to be adopted, in an attempt to achieve some sort of comparability. The standard Engle and Granger two-step cointegration procedure was therefore used in each case, even when it may not have been the most appropriate, for example in the cases where the variables did not form a cointegrated set or where the first difference terms were non-stationary. Bearing these points in mind, the results presented above can be summarised as follows.

Taking the results as a whole, it could be suggested that the most important determinant of post-compulsory education choices is prior academic performance during compulsory schooling. This is the variable which appeared in the preceding discussion of the results more than any other. It can be supposed that greater success during their days of compulsory schooling gives young people greater confidence in their own ability to continue their studies to a higher level. It could also be suggested that this effect is more important for females than for males. In the long-run equations for the three countries for which a measure of 'education success' was available, this variable is the single most important determinant of female participation rates in every country and for every age group. In the short-run equations, seven significantly positive coefficients on the 'education success' variable are obtained, more than for any other variable, with five of these seven significant coefficients appearing in female equations.

The policy implication of this finding is that it is important to concentrate on young people early in their lives, as their performance during the years of compulsory schooling seems to affect their future decisions concerning the continuation of their education. For example, in Sweden the decision whether to join the academic or the general stream is taken in year 6 of the Comprehensive school, and is presumably decided on the basis of performance even earlier in the school career. In England, 'prior success' was measured by exam success at age 16, but even in this case, results at that age will usually be the product of the decisions and efforts of earlier years. Such a conclusion is consistent with Swedish evidence that it is possible to predict who will drop out of education on the basis of characteristics at a young age (Murray, 1997). If countries want to produce a well-qualified population, it would therefore seem important to consider the earlier years spent by individuals in the education system, as well as their final years.

For males, the 'education success' effect remains important in almost all cases, but is often superceded by other effects. In the Netherlands, the level of per capita consumer expenditure appears to be the key determinant of male education participation choices, while British males seem to be most influenced by the ratio of professional to manual earnings. In Germany, the earnings elasticities are also the largest, but are very erratic, and in the short-run equations it is the 'education success' variable which attracts a strongly significant coefficient, so that, in Germany at least, the influences on males and females are similar. The earnings and expenditure effects for females in the other countries are, with one or two exceptions, much smaller than their male equivalents, frequently insignificant, and sometimes even of the wrong (negative) sign.

The most robust finding of the study would seem to be small, positive effect of youth 
unemployment levels on participation rates. A long-run unemployment elasticity of around 0.1 is consistently found across countries, age cohorts and genders. The maximum size the elasticity rises to is 0.2 . That the unemployment effect is of some relevance is revealed by five statistically significant short-run unemployment coefficients, one female and two male in the Netherlands, and one female and one male in Sweden. It would seem that rising youth unemployment has had a small part to play in the increasing participation in post-compulsory education in Europe, although the size of the estimated effect suggests that were jobs to be made available for young schoolleavers, there would be little effect on participation in education, those who want to stay-on doing so regardless.

Finally, the results of this study have little to add to the debate as to whether vocational training schemes are seen as a substitute for formal academic education, or whether they act as a complement to school education for the less academically gifted, who would not have stayed-on anyway. Data on young people's participation in training schemes could only be obtained for Sweden and England. The long-run equations in those two countries showed very little relationship between the proportions of a cohort participating in formal education and training programmes. In the short-run equations, there was one statistically significant coefficient for 17 year old men in Sweden, the negative sign of which suggests that vocational training may act as a substitute for formal education, but not too much should be read into this one coefficient. 
Figure 1a

16 Year Old Female Participation Rates

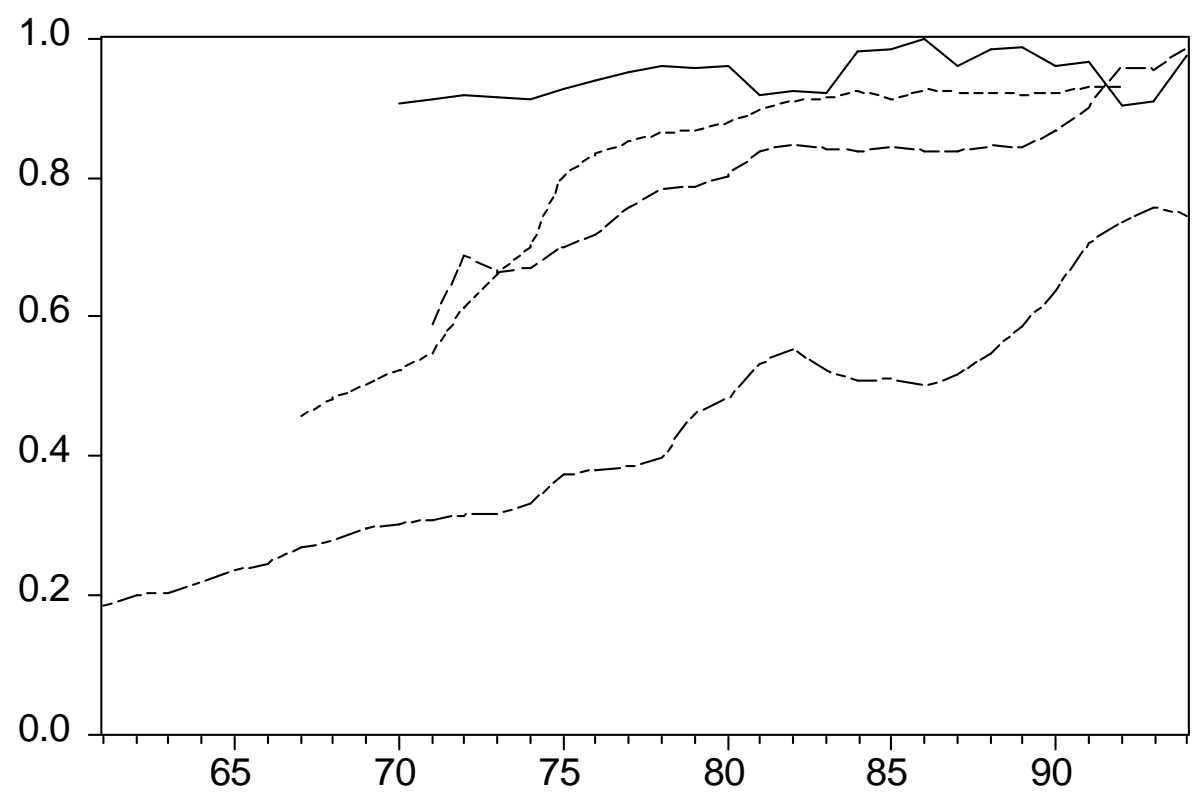

$\begin{array}{ll}\text { GERMANY } & ----- \text { SWEDEN } \\ \text { NETHERLANDS } & ---- \text { ENGLAND AND WALES }\end{array}$

Figure 1b

16 Year Old Male Participation Rates

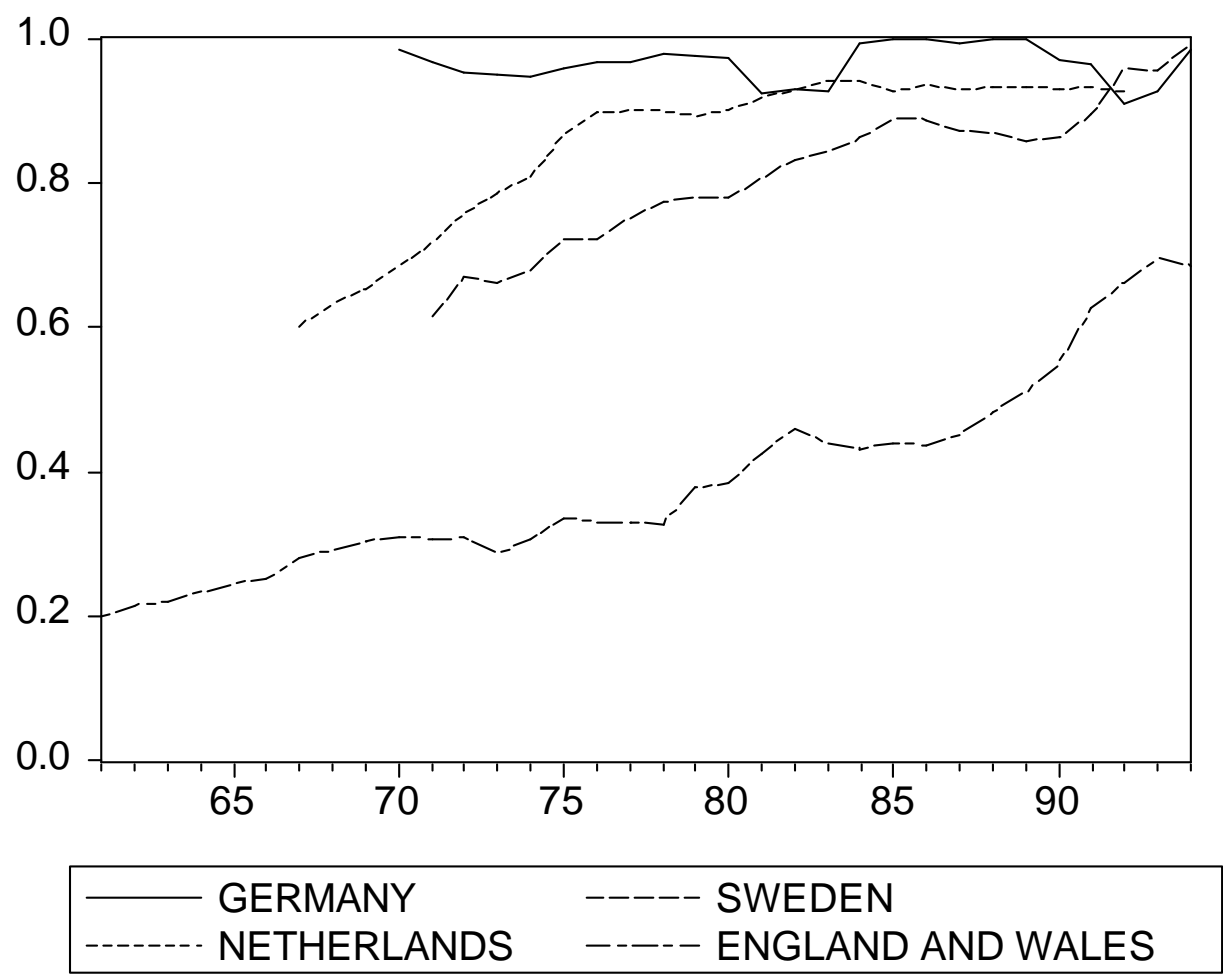


Figure 2a

17 Year Old Female Participation Rates

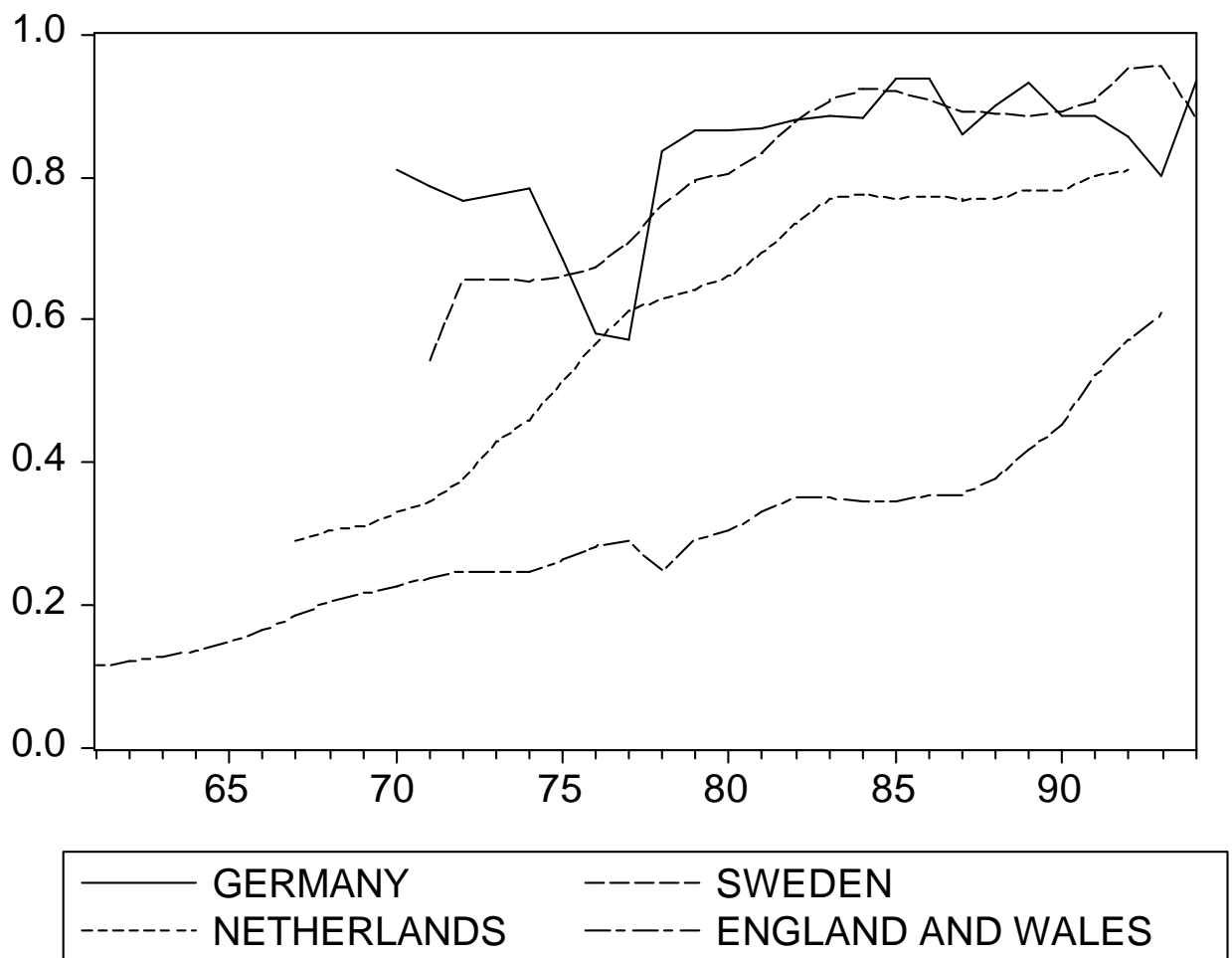

Figure 2b

17 Year Old Male Participation Rates

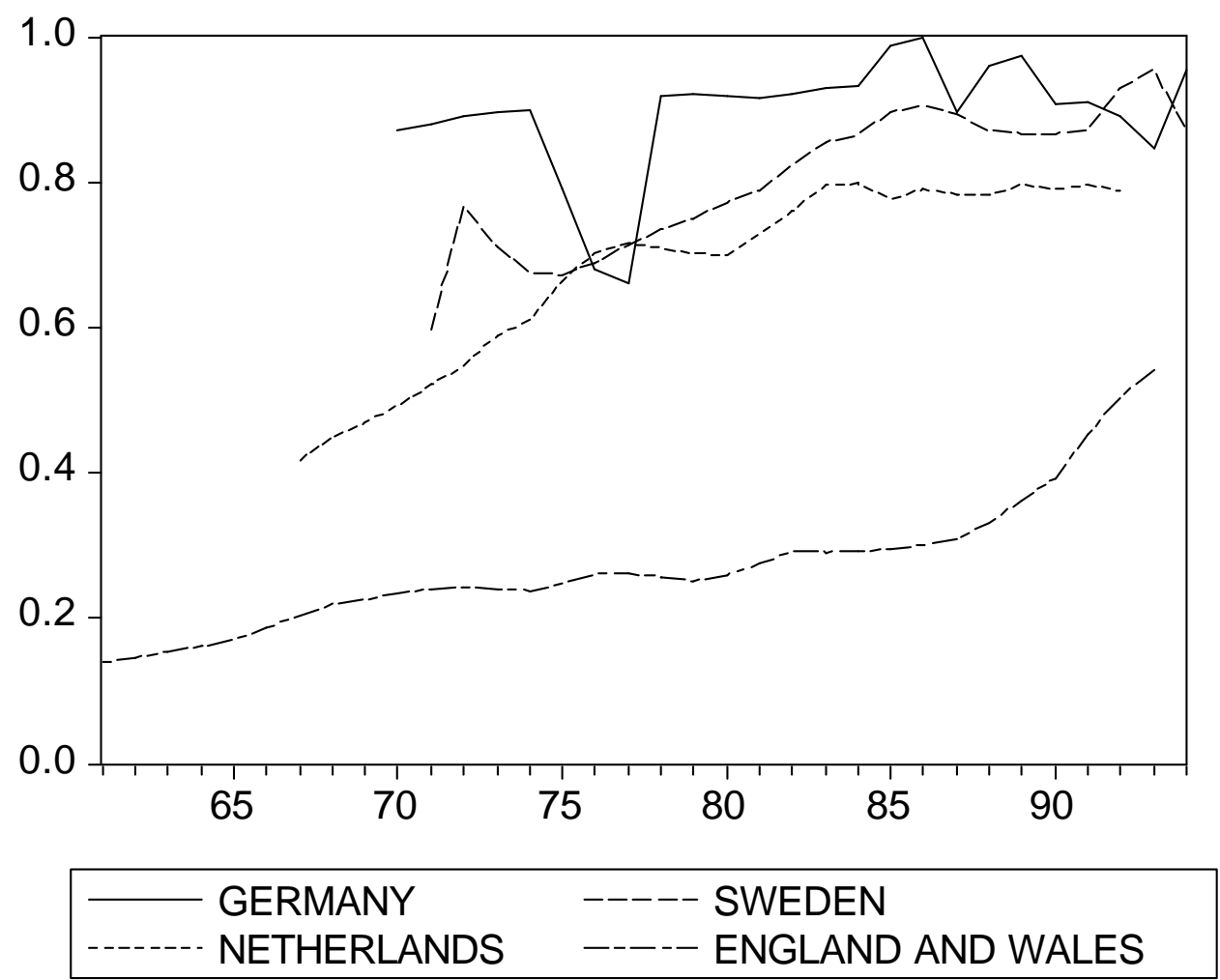


Figure 3a

18 Year Old Female Participation Rates

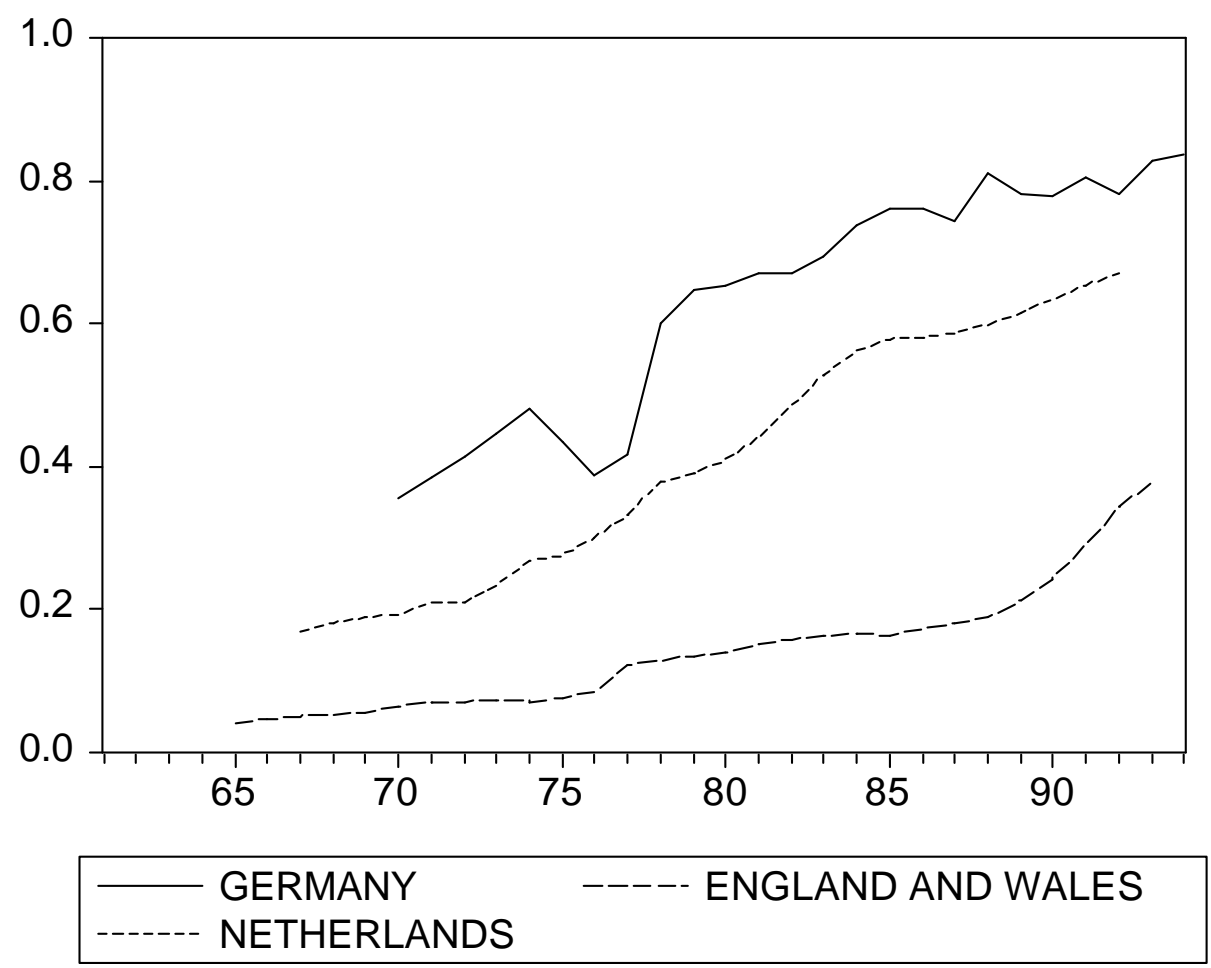

Figure 3b

18 Year Old Male Participation Rates

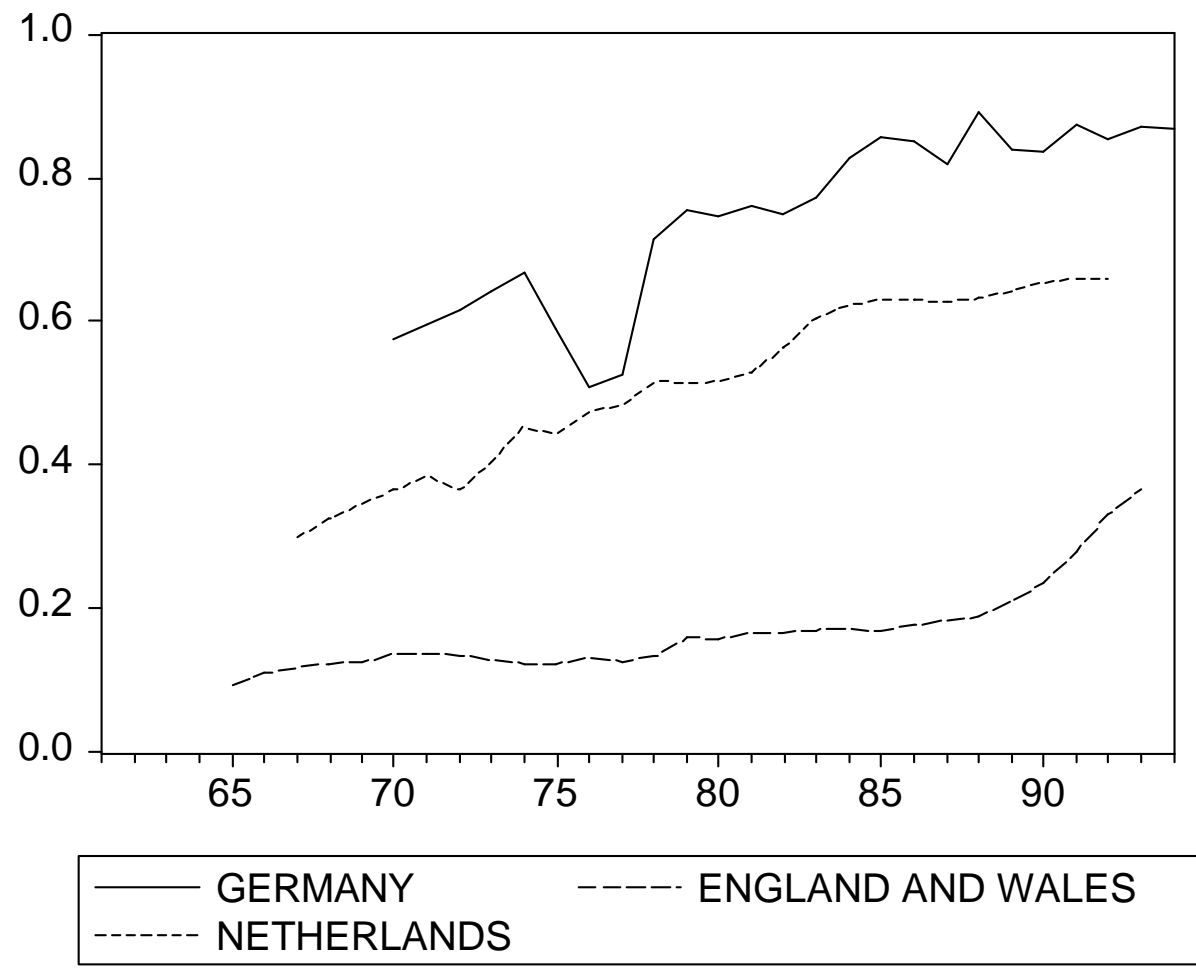


Table 1

Augmented Dickey-Fuller Tests for the Existence of Unit Roots for all Variables Under Consideration (Germany)

\begin{tabular}{lll}
\hline & & \multicolumn{2}{c}{ ADF test statistic } \\
\cline { 2 - 3 } variable & level & first difference \\
\hline $\log$ (participation/1-participation) & (16 year old female) & $-3.826^{* *}$ \\
$\log$ (participation/1-participation) $\quad(16$ year old male) & -2.085 & $-3.443^{*}$ \\
$\log$ (participation/1-participation) $\quad(17$ year old female) & -2.572 & $-4.333^{* *}$ \\
$\log$ (participation/1-participation) $(17$ year old male) & -2.915 & $-5.126^{* * *}$ \\
$\log$ (participation/1-participation) $(18$ year old female) & -2.679 & $-4.064^{* *}$ \\
$\log$ (participation/1-participation) (18 year old male) & -2.617 & $-4.282^{* *}$ \\
$\log$ (youth unemployment rate) (female) & -2.835 & $-3.692^{* *}$ \\
$\log$ (youth unemployment rate) (male) & -1.777 & -3.040 \\
$\log$ (ratio of 'technical' to manual earnings) (female) & -2.323 & $-4.558^{* * *}$ \\
$\log$ (ratio of 'technical' to manual earnings) (male) & -2.667 & $-3.787^{* *}$ \\
$\log$ (GCSE success) (female) & -2.397 & $-4.371^{* *}$ \\
$\log$ (GCSE success) (male) & -0.871 & -3.233 \\
\hline
\end{tabular}

Notes: The ADF test statistic is a test of the null hypothesis that a unit root exists, that is that the series in question is non-stationary. For the levels variables, equation 3 in the text is estimated and the test statistic is the t-statistic to test that the coefficient on the lagged level variable (f) is zero. In each case, sufficient lagged difference terms are included to eliminate serial correlation in the residuals, as tested using an LM test. Similar equations are estimated for the first differenced variables. $* * *$ significant at $1 \%$ significance level. $* *$ significant at $5 \%$ significance level. * significant at $10 \%$ significance level. $\ddagger$ reject null hypothesis of a unit root when tested jointly with the significance of the time trend.

Table 2

Augmented Dickey-Fuller Tests for the Existence of Unit Roots for all Variables Under Consideration (Netherlands)

\begin{tabular}{|c|c|c|}
\hline \multirow[b]{2}{*}{ variable } & \multicolumn{2}{|c|}{ ADF test statistic } \\
\hline & level & first difference \\
\hline $\log$ (participation/1-participation) (16 year old female) & -0.533 & -2.815 \\
\hline $\log$ (participation/1-participation) (16 year old male) & -0.657 & $-3.567 *$ \\
\hline $\log$ (participation/1-participation) (17 year old female) & -1.178 & -2.782 \\
\hline $\log$ (participation/1-participation) (17 year old male) & -1.045 & $-4.879 * * *$ \\
\hline $\log$ (participation/1-participation) (18 year old female) & -1.753 & -2.892 \\
\hline $\log$ (participation/1-participation) (18 year old male) & -1.464 & $-4.043 * *$ \\
\hline $\log$ (youth unemployment rate) (female) & 0.361 & -2.120 \\
\hline $\log$ (youth unemployment rate) (male) & -1.151 & -2.861 \\
\hline $\log$ (ratio of level 5-7 to level 3 earnings) & $-3.470 *$ & $-3.881 * *$ \\
\hline $\log$ (real per capita consumer expenditure) & -1.224 & $-3.821 * *$ \\
\hline
\end{tabular}

Notes: see table 1 
Table 3

Augmented Dickey-Fuller Tests for the Existence of Unit Roots for all Variables Under Consideration(Sweden)

\begin{tabular}{|c|c|c|}
\hline \multirow[b]{2}{*}{ variable } & \multicolumn{2}{|c|}{ ADF test statistic } \\
\hline & level & first difference \\
\hline $\log$ (participation/1-participation) (16 year old female) & -1.527 & 0.257 \\
\hline $\log$ (participation/1-participation) (16 year old male) & -1.557 & $2.359 \ddagger$ \\
\hline $\log$ (participation/1-participation) (17 year old female) & -2.785 & $-4.714 * * *$ \\
\hline $\log$ (participation/1-participation) (17 year old male) & -2.636 & $-5.123 * * *$ \\
\hline $\log$ (youth unemployment rate) (female) & -2.243 & -3.032 \\
\hline $\log$ (youth unemployment rate) (male) & -2.261 & $-3.183 \ddagger$ \\
\hline $\log$ (ratio of 'qualified' to 'routine' earnings) (female) & -2.275 & -2.234 \\
\hline $\log$ (ratio of 'management' to 'routine' earnings) (male) & -1.571 & $-3.847 * *$ \\
\hline $\log$ (prop. on academic English course in grade 9) (fem) & $-3.643 * *$ & $-4.719 * * *$ \\
\hline $\log$ (prop on academic English course in grade 9)(male) & -2.072 & $-5.032 * * *$ \\
\hline $\log$ (real per capita consumer expenditure) & -3.122 & -2.582 \\
\hline $\log$ (proportion of 16 year olds on YTS schemes) (fem) & -3.095 & $-4.512 * * *$ \\
\hline $\log$ (proportion of 16 year olds on YTS schemes)(male) & -3.192 & $-4.448 * * *$ \\
\hline
\end{tabular}

Notes: see table 1

Table 4

Augmented Dickey-Fuller Tests for the Existence of Unit Roots for all Variables Under Consideration (England and Wales)

\begin{tabular}{llcc}
\hline & & \multicolumn{2}{c}{ ADF test statistic } \\
\cline { 3 - 4 } variable & & level & first difference \\
\hline $\log$ (participation/1-participation) & (16 year old female) & -3.180 & $-3.550^{*}$ \\
$\log$ (participation/1-participation) & (16 year old male) & -1.632 & -3.120 \\
$\log$ (participation/1-participation) & (17 year old female) & -1.157 & -2.549 \\
$\log$ (participation/1-participation) & (17 year old male) & -1.511 & -2.069 \\
$\log$ (participation/1-participation) & (18 year old female) & -2.203 & -2.666 \\
$\log$ (participation/1-participation) & $(18$ year old male) & 0.037 & -2.425 \\
$\log$ (youth unemployment rate) (female) & -1.602 & $-4.358^{* * *}$ \\
$\log$ (youth unemployment rate) (male) & -1.297 & $-5.254^{* * *}$ \\
$\log$ (ratio of professional to manual earnings) (female) & -1.358 & $-4.044^{* *}$ \\
$\log$ (ratio of professional to manual earnings) (male) & -1.325 & $-3.546^{*}$ \\
$\log$ (GCSE success) (female) & -0.875 & $-3.593^{* *}$ \\
$\log$ (GCSE success) (male) & -0.163 & $-3.105 *$ \\
$\log$ (real per capita consumer expenditure) & -2.904 & $-4.456^{* * *}$ \\
proportion of 16 year olds on YTS schemes & -3.149 & -1.882 \\
\hline
\end{tabular}

Notes: see table 1 
Table 5

Long-run Determinants of Participation in Post-compulsory Education (Germany)

\begin{tabular}{|c|c|c|c|c|c|c|}
\hline \multirow[b]{2}{*}{ variable } & \multicolumn{3}{|c|}{ Females: coefficient (elasticity) } & \multicolumn{3}{|c|}{ Males: coefficient (elasticity) } \\
\hline & 16 year olds & $\begin{array}{l}17 \text { year } \\
\text { olds }\end{array}$ & $\begin{array}{l}18 \text { year } \\
\text { olds }\end{array}$ & $\begin{array}{l}16 \text { year } \\
\text { olds }\end{array}$ & $\begin{array}{l}17 \text { year } \\
\text { olds }\end{array}$ & $\begin{array}{l}18 \text { year } \\
\text { olds }\end{array}$ \\
\hline constant & 11.211 & 5.822 & 1.912 & 27.590 & 9.115 & 1.343 \\
\hline $\log$ (youth unemp) & $\begin{array}{c}0.068 \\
(0.004)\end{array}$ & $\begin{array}{c}-0.285 \\
(-0.049)\end{array}$ & $\begin{array}{c}-0.146 \\
(-0.052)\end{array}$ & $\begin{array}{c}0.646 \\
(0.022)\end{array}$ & $\begin{array}{c}0.053 \\
(0.006)\end{array}$ & $\begin{array}{c}-0.192 \\
(-0.049)\end{array}$ \\
\hline $\log$ (earnings ratio) & $\begin{array}{l}-28.225 \\
(-1.540)\end{array}$ & $\begin{array}{c}-9.400 \\
(-1.613)\end{array}$ & $\begin{array}{c}1.372 \\
(0.491)\end{array}$ & $\begin{array}{l}-62.023 \\
(-2.071)\end{array}$ & $\begin{array}{l}-13.233 \\
(-1.380)\end{array}$ & $\begin{array}{c}5.305 \\
(1.341)\end{array}$ \\
\hline $\begin{array}{l}\log (\text { 'mittlere } \\
\text { Reife') }\end{array}$ & $\begin{array}{c}3.890 \\
(0.212)\end{array}$ & $\begin{array}{c}2.785 \\
(0.478)\end{array}$ & $\begin{array}{c}2.206 \\
(0.789)\end{array}$ & $\begin{array}{c}10.134 \\
(0.338)\end{array}$ & $\begin{array}{c}4.016 \\
(0.419)\end{array}$ & $\begin{array}{c}1.895 \\
(0.479)\end{array}$ \\
\hline & 23 & 22 & 21 & 23 & 22 & 21 \\
\hline no of observations & 0.463 & 0.616 & 0.888 & 0.449 & 0.245 & 0.837 \\
\hline $\mathrm{R}^{2}$ & 5.468 & 9.639 & 45.043 & 5.161 & 1.947 & 29.004 \\
\hline $\mathrm{F}$ & 2.175 & 1.518 & 1.201 & 1.132 & 1.693 & 1.292 \\
\hline $\begin{array}{l}\mathrm{DW} \\
\mathrm{ADF}\end{array}$ & -2.744 & $-3.635 *$ & $-4.216 * *$ & -2.504 & -3.174 & $-3.208 *$ \\
\hline
\end{tabular}

Notes: The dependent variable is $\ln (\mathrm{P} / 1-\mathrm{P})$, as described in the text, where $\mathrm{P}$ is the proportion of the appropriate age group remaining in full-time education. DW is the Durbin-Watson test statistic for serial correlation in the residuals. ADF is the augmented Dickey-Fuller statistic for testing the stationarity of the residuals. A rejection of the null hypothesis of a unit root in the residuals implies the variables are cointegrated.

Table 6

Long-run Determinants of Participation in Post-compulsory Education (Netherlands)

\begin{tabular}{lcccccc}
\hline & \multicolumn{2}{c}{ Females: coefficient (elasticity) } & \multicolumn{3}{c}{ Males: coefficient (elasticity) } \\
\cline { 2 - 7 } variable & 16 year olds & 17 year olds & $\begin{array}{l}18 \text { year } \\
\text { olds }\end{array}$ & 16 yearolds & 17 year olds & 18 year olds \\
& & & & & \\
\hline constant & -33.944 & -25.280 & -24.097 & -23.804 & -16.911 & -14.809 \\
$\log$ (youth unemp) & 0.547 & 0.365 & 0.105 & 0.546 & 0.302 & 0.095 \\
& $(0.098)$ & $(0.135)$ & $(0.060)$ & $(0.069)$ & $(0.090)$ & $(0.045)$ \\
$\log$ (earnings ratio) & -0.583 & -2.089 & -4.277 & -0.046 & -0.936 & -2.287 \\
& $(-0.105)$ & $(-0.775)$ & $-2.44)$ & $(-0.006)$ & $(-0.280)$ & $-1.075)$ \\
log (per capita & 3.567 & 2.684 & 2.648 & 2.533 & 1.808 & 1.634 \\
expenditure) & $(0.642)$ & $(0.996)$ & $(1.509)$ & $(0.322)$ & $(0.541)$ & $(0.768)$ \\
& & & & & & \\
no of observations & 24 & 24 & 24 & 24 & 24 & 24 \\
R & 0.967 & 0.982 & 0.988 & 0.982 & 0.980 & 0.985 \\
F & 193.74 & 370.43 & 559.51 & 370.29 & 326.08 & 450.11 \\
DW & 1.359 & 0.976 & 1.051 & 1.234 & 1.171 & 1.462 \\
ADF & $-3.409 *$ & $-4.079 * *$ & -2.776 & $-3.769 * *$ & $-4.013 * *$ & $-5.277 * * *$ \\
\hline
\end{tabular}

Notes: see Table 5 
Table 7

Long-run Determinants of Participation in Post-compulsory Education (Sweden)

\begin{tabular}{|c|c|c|c|c|}
\hline \multirow[b]{2}{*}{ variable } & \multicolumn{2}{|c|}{$\begin{array}{c}\text { Females: coefficient } \\
\text { (elasticity) }\end{array}$} & \multicolumn{2}{|c|}{$\begin{array}{l}\text { Males: coefficient } \\
\text { (elasticity) }\end{array}$} \\
\hline & 16 year olds & 17 year olds & 16 year olds & 17 year olds \\
\hline constant & -60.553 & -4.643 & -74.180 & -63.727 \\
\hline $\log$ (youth unemp) & $\begin{array}{c}0.923 \\
(0.189)\end{array}$ & $\begin{array}{l}-0.130 \\
(-0.024)\end{array}$ & $\begin{array}{c}0.825 \\
(0.162)\end{array}$ & $\begin{array}{c}0.386 \\
(0.075)\end{array}$ \\
\hline $\log$ (earnings ratio) & $\begin{array}{c}0.802 \\
(0.164)\end{array}$ & $\begin{array}{l}-2.562 \\
(-0.476)\end{array}$ & $\begin{array}{l}1.970 \\
(0.386)\end{array}$ & $\begin{array}{c}0.160 \\
(0.031)\end{array}$ \\
\hline $\log$ (academic English course in grade 9) & $\begin{array}{c}6.126 \\
(1.253)\end{array}$ & $\begin{array}{l}10.610 \\
(1.973)\end{array}$ & $\begin{array}{l}2.873 \\
(0.563)\end{array}$ & $\begin{array}{l}1.241 \\
(0.240)\end{array}$ \\
\hline $\log$ (per capita expenditure) & $\begin{array}{c}5.578 \\
(1.141)\end{array}$ & $\begin{array}{c}0.707 \\
(0.131)\end{array}$ & $\begin{array}{l}6.770 \\
(1.327)\end{array}$ & $\begin{array}{l}5.885 \\
(1.138)\end{array}$ \\
\hline $\log$ (youth training) & $\begin{array}{c}0.333 \\
(0.068)\end{array}$ & $\begin{array}{c}0.259 \\
(0.048)\end{array}$ & $\begin{array}{c}0.144 \\
(0.028)\end{array}$ & $\begin{array}{c}0.041 \\
(0.008)\end{array}$ \\
\hline no of observations & 25 & 24 & 25 & 24 \\
\hline $\mathrm{R}^{2}$ & 0.816 & 0.757 & 0.775 & 0.656 \\
\hline $\mathrm{F}$ & 16.823 & 11.220 & 13.062 & 6.864 \\
\hline DW & 1.032 & 1.103 & 1.053 & 0.892 \\
\hline $\mathrm{ADF}$ & -2.850 & -3.100 & $-3.656 * *$ & -2.426 \\
\hline
\end{tabular}

Notes: see Table 5

Table 8

Long-run Determinants of Participation in Post-compulsory Education (England and Wales)

\begin{tabular}{|c|c|c|c|c|c|c|}
\hline \multirow[b]{2}{*}{ variable } & \multicolumn{3}{|c|}{ Females: coefficient (elasticity) } & \multicolumn{3}{|c|}{ Males: coefficient (elasticity) } \\
\hline & 16 year olds & 17 year olds & $\begin{array}{l}18 \text { year } \\
\text { olds }\end{array}$ & 16 year olds & $\begin{array}{l}17 \text { year } \\
\text { olds }\end{array}$ & $\begin{array}{l}18 \text { year } \\
\text { olds }\end{array}$ \\
\hline constant & 4.059 & -1.401 & -9.117 & -0.021 & -3.748 & -1.329 \\
\hline $\log$ (youth unemp) & $\begin{array}{c}0.182 \\
(0.104)\end{array}$ & $\begin{array}{c}0.155 \\
(0.109)\end{array}$ & $\begin{array}{c}0.235 \\
(0.202)\end{array}$ & $\begin{array}{c}0.094 \\
(0.058)\end{array}$ & $\begin{array}{c}0.096 \\
(0.069)\end{array}$ & $\begin{array}{c}0.024 \\
(0.020)\end{array}$ \\
\hline $\log$ (earnings ratio) & $\begin{array}{c}0.122 \\
(0.070)\end{array}$ & $\begin{array}{c}0.552 \\
(0.387)\end{array}$ & $\begin{array}{l}-0.684 \\
(-0.588)\end{array}$ & $\begin{array}{l}1.923 \\
(1.179)\end{array}$ & $\begin{array}{l}1.689 \\
(1.222)\end{array}$ & $\begin{array}{r}0.840 \\
(0.699)\end{array}$ \\
\hline $\log$ (GCSE success) & $\begin{array}{l}1.893 \\
(1.084)\end{array}$ & $\begin{array}{c}1.567 \\
(1.098)\end{array}$ & $\begin{array}{c}1.785 \\
(1.533)\end{array}$ & $\begin{array}{c}1.496 \\
(0.917)\end{array}$ & $\begin{array}{l}1.225 \\
(0.886)\end{array}$ & $\begin{array}{c}2.394 \\
(1.992)\end{array}$ \\
\hline $\log$ (per capital expenditure) & $\begin{array}{l}-0.253 \\
(-0.145)\end{array}$ & $\begin{array}{c}0.461 \\
(0.323)\end{array}$ & $\begin{array}{c}1.793 \\
(1.540)\end{array}$ & $\begin{array}{c}0.143 \\
(0.088)\end{array}$ & $\begin{array}{c}0.667 \\
(0.482)\end{array}$ & $\begin{array}{r}0.463 \\
(0.385)\end{array}$ \\
\hline youth training & $\begin{array}{c}0.632 \\
(0.030)\end{array}$ & $\begin{array}{l}-0.356 \\
(-0.021)\end{array}$ & $\begin{array}{l}-0.328 \\
(-0.026)\end{array}$ & $\begin{array}{c}0.116 \\
(0.006)\end{array}$ & $\begin{array}{l}-1.127 \\
(-0.069)\end{array}$ & $\begin{array}{l}-0.317 \\
(-0.025)\end{array}$ \\
\hline $\begin{array}{l}\text { raising of school leaving } \\
\text { age }\end{array}$ & 0.146 & 0.068 & -0.169 & 0.283 & 0.199 & 0.015 \\
\hline & 34 & 32 & 29 & 34 & 32 & 29 \\
\hline no of observations & 0.972 & 0.986 & 0.967 & 0.967 & 0.977 & 0.947 \\
\hline $\mathrm{R}^{2}$ & 155.93 & 297.18 & 106.53 & 131.98 & 177.30 & 65.50 \\
\hline $\mathrm{F}$ & 1.041 & 1.704 & 0.835 & 1.390 & 1.643 & 1.180 \\
\hline DW & $-4.331 * * *$ & $-4.886 * * *$ & -2.883 & $-4.102 * *$ & $-3.449 *$ & -2.753 \\
\hline
\end{tabular}


Notes: see Table 5

Table 9

Short-run Dynamic Equations for Participation in Post-compulsory Education (Germany)

\begin{tabular}{|c|c|c|c|c|c|c|}
\hline \multirow[b]{2}{*}{ variable } & \multicolumn{3}{|c|}{ Females: coefficient (s.e.) } & \multicolumn{3}{|c|}{ Males: coefficient (s.e.) } \\
\hline & 16 year olds & $\begin{array}{l}17 \text { year } \\
\text { olds }\end{array}$ & $\begin{array}{l}18 \text { year } \\
\text { olds }\end{array}$ & $\begin{array}{l}16 \text { year } \\
\text { olds }\end{array}$ & $\begin{array}{l}17 \text { year } \\
\text { olds }\end{array}$ & $\begin{array}{l}18 \text { year } \\
\text { olds }\end{array}$ \\
\hline \multirow[t]{2}{*}{ constant } & -0.09 & 0.06 & -0.09 & -0.25 & -0.07 & $-0.21 * *$ \\
\hline & $(0.23)$ & $(0.15)$ & $(0.09)$ & $(0.29)$ & $(0.41)$ & $(0.08)$ \\
\hline \multirow[t]{2}{*}{$\mathrm{L}\{?[\log (\mathrm{P} / 1-\mathrm{P})]\}$} & -0.04 & $0.73 *$ & $0.74 * *$ & 0.15 & 0.21 & $0.83 * * *$ \\
\hline & $(0.21)$ & $(0.38)$ & $(0.31)$ & $(0.23)$ & $(0.28)$ & $(0.28)$ \\
\hline \multirow[t]{2}{*}{$?[\log$ (youth unemployment)] } & -0.86 & 0.36 & -0.16 & -0.73 & -0.52 & -0.05 \\
\hline & $(0.81)$ & $(0.55)$ & $(0.18)$ & $(0.79)$ & $(0.99)$ & $(0.18)$ \\
\hline \multirow[t]{2}{*}{$?[\log ($ earnings ratio) $]$} & -4.07 & -5.34 & 3.39 & 1.94 & 24.52 & 6.90 \\
\hline & $(13.50)$ & $(7.19)$ & $(3.44)$ & $(27.36)$ & $(35.06)$ & $(6.44)$ \\
\hline \multirow[t]{2}{*}{$?[\log ($ 'mittlere Reife')] } & 5.66 & -1.51 & $2.60 *$ & $11.37 *$ & 0.92 & $5.53 * * *$ \\
\hline & $(4.13)$ & $(3.99)$ & $(1.31)$ & $(6.04)$ & $(8.81)$ & $(1.57)$ \\
\hline \multirow{2}{*}{$\mathrm{L}(\mathrm{ECM})$} & $-1.04 * * *$ & $-0.99 * * *$ & $-1.04 * * *$ & $-0.61 * *$ & $-0.98 * *$ & $-1.30 * * *$ \\
\hline & $(0.31)$ & $(0.32)$ & $(0.30)$ & $(0.23)$ & $(0.36)$ & $(0.27)$ \\
\hline no of observations & 21 & 21 & 20 & 21 & 21 & 20 \\
\hline $\mathrm{R}^{2}$ & 0.632 & 0.466 & 0.475 & 0.465 & 0.444 & 0.666 \\
\hline $\mathrm{F}$ & 5.149 & 2.620 & 2.529 & 2.603 & 2.398 & 5.589 \\
\hline LM & 0.312 & 0.091 & 0.059 & 0.687 & 0.225 & 0.957 \\
\hline
\end{tabular}

Notes: The dependent variable is? $\ln (\mathrm{P} / 1-\mathrm{P})$, as described in the text, where $\mathrm{P}$ is the proportion of the appropriate age group remaining in full-time education. ? is the first difference operator, $\mathrm{L}$ is the lag operator. *** indicates statistical significance at the $1 \%$ significance level, $* *$ at the $5 \%$ significance level and $*$ at the $10 \%$ significance level. ECM is the error correction mechanism; that is the residuals, $\mathrm{P}_{\mathrm{t}}-\mathrm{bX}$, from the long-run relevant cointegrating regression. LM is the $\mathrm{F}$ statistic from a Lagrange Multiplier test for serial correlation in the residuals.

Table 10

Short-run Dynamic Equations for Participation in Post-compulsory Education (Netherlands)

\begin{tabular}{|c|c|c|c|c|c|c|}
\hline \multirow[b]{2}{*}{ variable } & \multicolumn{3}{|c|}{ Females: coefficient (s.e.) } & \multicolumn{3}{|c|}{ Males: coefficient (s.e.) } \\
\hline & 16 year olds & 17 year olds & 18 year olds & 16 year olds & 17 year olds & 18 year olds \\
\hline
\end{tabular}




\begin{tabular}{|c|c|c|c|c|c|c|}
\hline \multirow{3}{*}{ constant } & \multicolumn{3}{|c|}{ Females: coefficient (s.e.) } & \multicolumn{3}{|c|}{ Males: coefficient (s.e.) } \\
\hline & 0.07 & 0.01 & 0.03 & 0.03 & 0.01 & -0.03 \\
\hline & $(0.05)$ & $(0.03)$ & $(0.03)$ & $(0.03)$ & $(0.02)$ & $(0.02)$ \\
\hline \multirow{2}{*}{$\mathrm{L}\{?[\log (\mathrm{P} / 1-\mathrm{P})]\}$} & $0.45 *$ & $0.48 * *$ & 0.27 & $0.26 * *$ & $0.41 * * *$ & $0.41 * *$ \\
\hline & $(0.23)$ & $(0.20)$ & $(0.22)$ & $(0.12)$ & $(0.14)$ & $(0.19)$ \\
\hline \multirow{2}{*}{$?[\log ($ youth unemployment) $]$} & 0.19 & $0.17 *$ & 0.10 & $0.44 * * *$ & $0.20 * * *$ & 0.03 \\
\hline & $(0.15)$ & $(0.08)$ & $(0.06)$ & $(0.08)$ & $(0.06)$ & $(0.05)$ \\
\hline \multirow{2}{*}{$?[\log$ (earnings ratio) $]$} & 1.32 & -1.23 & $-1.95 *$ & $1.88 *$ & 0.66 & $-2.11 * * *$ \\
\hline & $(1.86)$ & $(1.08)$ & $(1.02)$ & $(1.02)$ & $(0.76)$ & $(0.72)$ \\
\hline \multirow[t]{2}{*}{ ? [log (per capita expenditure)] } & -0.70 & 0.59 & 0.87 & 0.81 & 0.78 & $1.89 * * *$ \\
\hline & $(1.23)$ & $(0.66)$ & $(0.58)$ & $(0.68)$ & $(0.52)$ & $(0.45)$ \\
\hline \multirow[t]{2}{*}{$\mathrm{L}(\mathrm{ECM})$} & $-0.47 * *$ & $-0.36 *$ & -0.33 & $-0.67 * * *$ & $-0.77 * * *$ & $-1.12 * * *$ \\
\hline & $(0.20)$ & $(0.19)$ & $(0.21)$ & $(0.19)$ & $(0.21)$ & $(0.26)$ \\
\hline no of observations & 23 & 23 & 23 & 23 & 23 & 23 \\
\hline $\mathrm{R}^{2}$ & 0.431 & 0.540 & 0.368 & 0.813 & 0.751 & 0.639 \\
\hline $\mathrm{F}$ & 2.574 & 3.991 & 1.981 & 14.740 & 10.237 & 6.028 \\
\hline LM & 1.530 & 0.127 & 0.391 & 1.626 & 1.099 & 0.154 \\
\hline
\end{tabular}

Notes: see Table 9

Table 11

Short-run Dynamic Equations for Participation in Post-compulsory Education (Sweden)

\begin{tabular}{|c|c|c|c|c|}
\hline \multirow[b]{2}{*}{ variable } & \multicolumn{2}{|c|}{ Females: coefficient (s.e.) } & \multicolumn{2}{|c|}{ Males: coefficient (s.e.) } \\
\hline & 16 year olds & 17 year olds & 16 year olds & 17 year olds \\
\hline \multirow[t]{2}{*}{ constant } & $0.10^{*}$ & -0.07 & $0.22 *$ & -0.18 \\
\hline & $(0.05)$ & $(0.10)$ & $(0.12)$ & $(0.46)$ \\
\hline \multirow[t]{2}{*}{$\mathrm{L}\{?[\log (\mathrm{P} / 1-\mathrm{P})]\}$} & $0.45^{*}$ & $0.96 * *$ & -0.03 & 0.56 \\
\hline & $(0.21)$ & $(0.39)$ & $(0.42)$ & $(0.39)$ \\
\hline \multirow[t]{2}{*}{$?[\log ($ youth unemployment)] } & $0.42 * * *$ & 0.08 & -0.25 & $0.52 * *$ \\
\hline & $(0.14)$ & $(0.26)$ & $(0.33)$ & $(0.23)$ \\
\hline \multirow[t]{2}{*}{$?[\log$ (earnings ratio) $]$} & -0.77 & $11.97 *$ & 2.67 & -3.34 \\
\hline & $(3.27)$ & $(6.12)$ & $(3.85)$ & $(3.12)$ \\
\hline \multirow[t]{2}{*}{$?[\log ($ academic English in grade 9$)]$} & $-2.66 *$ & $4.62 *$ & -4.28 & 0.09 \\
\hline & $(1.42)$ & $(2.36)$ & $(3.00)$ & $(2.36)$ \\
\hline \multirow[t]{2}{*}{$?[\log$ (per capita expenditure)] } & $-1.38 * *$ & 5.81 & -2.01 & 4.44 \\
\hline & $(3.31)$ & $(4.35)$ & $(5.46)$ & $(3.65)$ \\
\hline \multirow[t]{2}{*}{$?[\log$ (youth training)] } & 0.17 & 0.32 & 0.64 & $-0.53 * *$ \\
\hline & $(0.16)$ & $(0.32)$ & $(0.42)$ & $(0.24)$ \\
\hline \multirow[t]{2}{*}{$\mathrm{L}(\mathrm{ECM})$} & -0.00 & -0.74 & -0.47 & $-1.136 * * *$ \\
\hline & $(0.17)$ & $(0.22)$ & $(0.28)$ & $(0.34)$ \\
\hline no of observations & 23 & 22 & 24 & 22 \\
\hline $\mathrm{R}^{2}$ & 0.633 & 0.562 & 0.375 & 0.578 \\
\hline $\mathrm{F}$ & 3.014 & 2.081 & 1.369 & 2.222 \\
\hline LM & 0.897 & 2.333 & 1.230 & $4.547 * *$ \\
\hline
\end{tabular}

Notes: see Table 9

Table 12

Short-run Dynamic Equations for Participation in Post-compulsory Education (England and Wales)

\begin{tabular}{|c|c|c|c|c|c|c|}
\hline \multirow[b]{2}{*}{ variable } & \multicolumn{3}{|c|}{ Females: coefficient (s.e.) } & \multicolumn{3}{|c|}{ Males: coefficient (s.e.) } \\
\hline & 16 year olds & 17 year olds & 18 year olds & 16 year olds & 17 year olds & 18 year olds \\
\hline
\end{tabular}




\begin{tabular}{|c|c|c|c|c|c|c|}
\hline \multirow[b]{2}{*}{ constant } & \multicolumn{3}{|c|}{ Females: coefficient (s.e.) } & \multicolumn{3}{|c|}{ Males: coefficient (s.e.) } \\
\hline & $\begin{array}{c}0.01 \\
(0.03)\end{array}$ & $\begin{array}{c}0.03 \\
(0.03)\end{array}$ & $\begin{array}{l}-0.00 \\
(0.03)\end{array}$ & $\begin{array}{c}0.00 \\
(0.03)\end{array}$ & $\begin{array}{c}0.02 \\
(0.01)\end{array}$ & $\begin{array}{l}-0.03 \\
(0.03)\end{array}$ \\
\hline $\mathrm{L}\{?[\log (\mathrm{P} / 1-\mathrm{P})]\}$ & $\begin{array}{l}0.53 * * \\
(0.21)\end{array}$ & $\begin{array}{c}0.23 \\
(0.18)\end{array}$ & $\begin{array}{l}0.93 * * * \\
(0.16)\end{array}$ & $\begin{array}{l}0.49 * * \\
(0.21)\end{array}$ & $\begin{array}{l}0.67 * * * \\
(0.13)\end{array}$ & $\begin{array}{l}0.84 * * * \\
(0.22)\end{array}$ \\
\hline$?[\log$ (youth unemployment)] & $\begin{array}{c}0.02 \\
(0.07)\end{array}$ & $\begin{array}{c}0.07 \\
(0.06)\end{array}$ & $\begin{array}{l}-0.01 \\
(0.05)\end{array}$ & $\begin{array}{c}0.08 \\
(0.07)\end{array}$ & $\begin{array}{c}0.02 \\
(0.03)\end{array}$ & $\begin{array}{c}0.01 \\
(0.06)\end{array}$ \\
\hline$?$ [log (earnings ratio) $]$ & $\begin{array}{c}0.24 \\
(0.30)\end{array}$ & $\begin{array}{c}0.40 \\
(0.26)\end{array}$ & $\begin{array}{c}0.38 \\
(0.29)\end{array}$ & $\begin{array}{c}1.14 * \\
(0.56)\end{array}$ & $\begin{array}{l}0.71 * * \\
(0.25)\end{array}$ & $\begin{array}{l}0.99 * * \\
(0.39)\end{array}$ \\
\hline$?[\log (\mathrm{GCSE}$ success $)]$ & $\begin{array}{c}0.82 * \\
(0.41)\end{array}$ & $\begin{array}{l}0.93 * * * \\
(0.25)\end{array}$ & $\begin{array}{c}0.81^{*} \\
(0.39)\end{array}$ & $\begin{array}{l}0.88^{* *} \\
(0.37)\end{array}$ & $\begin{array}{c}0.23 \\
(0.15)\end{array}$ & $\begin{array}{c}1.26 \\
(0.79)\end{array}$ \\
\hline ? [log (per capita expenditure)] & $\begin{array}{l}-0.73 \\
(0.64)\end{array}$ & $\begin{array}{l}-0.33 \\
(0.56)\end{array}$ & $\begin{array}{l}-0.87 * \\
(0.43)\end{array}$ & $\begin{array}{l}-0.59 \\
(0.61)\end{array}$ & $\begin{array}{l}-0.31 \\
(0.31)\end{array}$ & $\begin{array}{l}-0.19 \\
(0.53)\end{array}$ \\
\hline$?[$ (youth training $)]$ & $\begin{array}{c}0.54 \\
(0.82)\end{array}$ & $\begin{array}{c}0.09 \\
(0.59)\end{array}$ & $\begin{array}{c}0.87 \\
(0.67)\end{array}$ & $\begin{array}{c}0.64 \\
(0.77)\end{array}$ & $\begin{array}{l}-0.46 \\
(0.34)\end{array}$ & $\begin{array}{c}1.47 \\
(0.90)\end{array}$ \\
\hline ? [raising of school leaving age] & $\begin{array}{l}-0.00 \\
(0.09)\end{array}$ & $\begin{array}{l}-0.01 \\
(0.08)\end{array}$ & $\begin{array}{l}-0.16^{*} \\
(0.08)\end{array}$ & $\begin{array}{l}-0.01 \\
(0.10)\end{array}$ & $\begin{array}{c}0.01 \\
(0.05)\end{array}$ & $\begin{array}{l}-0.06 \\
(0.08)\end{array}$ \\
\hline $\mathrm{L}(\mathrm{ECM})$ & $\begin{array}{l}-0.58^{* * *} \\
(0.20)\end{array}$ & $\begin{array}{l}-0.79 * * * \\
(0.23)\end{array}$ & $\begin{array}{l}-0.53^{* * *} \\
(0.17)\end{array}$ & $\begin{array}{l}-0.84 * * * \\
(0.26)\end{array}$ & $\begin{array}{l}-0.47 * * * \\
(0.15)\end{array}$ & $\begin{array}{l}-1.04 * * * \\
(0.35)\end{array}$ \\
\hline no of observations & 32 & 31 & 26 & 32 & 31 & 27 \\
\hline $\mathrm{R}^{2}$ & 0.468 & 0.553 & 0.669 & 0.471 & 0.766 & 0.619 \\
\hline $\mathrm{F}$ & 2.531 & 3.405 & 3.592 & 2.560 & 9.000 & 3.655 \\
\hline LM & 0.494 & 0.834 & 2.719 & 0.598 & 0.586 & 1.651 \\
\hline
\end{tabular}

Notes: see Table 9 


\section{Appendix \\ Data Sources}

\section{Germany}

\section{Proportion of age group in the post-compulsory education}

The numbers of 16 year olds, 17 year olds and 18 year olds, expressed as a proportion of the relevant age groups, defined separately for men and women

Source: Bundesministerium fur Bildung, Wissenschaft, Forschung und Technologie, Grung- und Struktur Daten, various issues.

\section{Youth unemployment rate}

The proportion of 20-24 year olds in the labour force who are out of work, looking for work and willing to start work, defined separately for men and women.

Source: OECD, Labour Force Statistics, various issues.

\section{Ratio of 'technical' to manual earnings}

The ratio of weekly kaufmannische und technische earnings to Arbeiter earnings in Industrie, defined separately for men and women.

Source: Statistisches Jahrbuch, various issues.

\section{Proportion of 16 year olds to achieve Mittlere Reife}

The total number of 16 year olds in each year who obtain Realschulabschluss, or, looking forward, go on to proceed successfully to the Abitur from a Gymnasien, expressed as a percentage of the 16 year old cohort, defined separately for men and women.

Sources: Statistisches Jahrbuch, various issues, (for numbers successful). Bundesministerium fur Bildung, Wissenschaft, Forschung und Technologie, Grung- und Struktur Daten, various issues, (for size of 16 year old cohort).

\section{Netherlands}

\section{Proportion of age group in the post-compulsory education}

The total number of 16 year olds, 17 year olds and 18 year olds in full-time education, expressed as a percentage of the total age groups. The rates are defined separately for males and females.

Source: Dutch Central Bureau of Statistics.

\section{Youth unemployment rate}


The percentage of the 15-24 year old age group to be unemployed, defined separately for men and women.

Source: Dutch Central Bureau of Statistics.

\section{Earnings Ratio}

Education categories are used to define the earnings ratio in the Netherlands. The ratio used is the ratio of the earnings of those at ISCED level 5/7, to those at ISCED level 3.

Source: Dutch Central Bureau of Statistics.

\section{Real per capita consumer expenditure}

The level of consumptive expenditures per head in 1990 prices.

Source: Dutch Central Bureau of Statistics.

\section{Sweden}

\section{Proportion of age group in the post-compulsory education}

For the participation rate of 16 year olds, the measure used, in general, is the transition, in per cent, between the Comprehensive school (Grundskola) and the Integrated upper secondary school (Gymnasieskola). In particular, the measure used in each year is as follows:

1. The numbers for 1969 and 1970 are based on a sample survey. About 5000 persons born in 1984 were asked what they were doing during the springs of 1969 and 1970.

2. For 1971, the female and male proportion are estimated as:

Transitional frequency $=\quad$ (proportion for $1970+$ proportion for 1972) $/ 2$

3. For 1972 and 1981 the transitional frequency is defined as:

Transitional frequency $=$ number of 16 year old pupils in Integrated upper secondary school in time $(\mathrm{t}) /$ the total population of 16 year olds in time $(\mathrm{t})$

4. For the years 1973 to 1980 , the transitional frequency is defined as:

Transitional frequency $=$ number of pupils in grade 9 of Comprehensive school in the autumn of year (t-1) / number of pupils in Integrated upper secondary school admitted in autumn $(\mathrm{t})$

5. For the year 1982, the total transitional frequency is known. The male and female transitional frequency is estimated using this information and information about male and female transition rates in 1981 and 1983.

6. For the years 1983 to 1991 and 1994 to 1995 the transitional frequency is defined as: 
Transitional frequency $=$ number of pupils admitted to Integrated upper secondary school in the autumn of year ( $\mathrm{t}$ ) / number of pupils in the $9^{\text {th }}$ grade of Comprehensive school in the spring of year $(t)$

7. For the years 1992 and 1993 the transition frequency is defined as:

Transitional frequency $=$ number of pupils admitted to Integrated upper secondary school in the autumn of year (t) / number of pupils in the $9^{\text {th }}$ grade of Comprehensive school in the autumn of year $(\mathrm{t}-$ 1)

In this case it is assumed that the admitted proportion of women is the same as the proportion of women in Comprehensive school grade 9 in time $(\mathrm{t}-1)$

The participation rates of 17 year olds are calculated as:

Transitional frequency $=$ number of pupils in the second year of Integrated upper secondary school in the autumn of year $(\mathrm{t}) /$ number of pupils in the $9^{\mathrm{h}}$ grade of Comprehensive school in the autumn of the year $(\mathrm{t}-2)$

Source: SOU 1980:30 for the years 1969 and 1970. Utbildningsstatistisk arsbok 1978 for the years 1973 to 1975. Utbildningsstatistisk arsbok 1981 for the years 1976 to 1980. Statistika Meddelanden, Serie U, various issues, for the years 1983 to 1993. Skolan i siffror for the years 1994 and 1995

\section{Youth unemployment rate}

The number of unemployed 16-19 year olds, expressed as a percentage of the total number of 1619 year olds in the labour force, based on a sample survey of the Swedish population. This is calculated separately for men and women.

Source: SCB Grundtabeller, Arbetskraftsundersokningen, Arsmedeltal, Table 1A, various issues.

\section{Earnings Ratio}

Data for industrial groups SNI 2 and 3 (mining, quarrying and manufacturing) were used. For males the ratio of 'management personnel' earnings to 'personnel with routine work' earnings was used. For females, the ratio used was 'personnel in responsible positions with qualified work' earnings to 'personnel with routine work' earnings.

\section{Education Success Variable}

For Sweden this variable is defined as the proportions of the male and female groups in grade 9 of Comprehensive school who attend an academic, as opposed to a general, course in English.

\section{Real Private per Capita Consumption Expenditure}

Total household consumption expenditure per capita, expressed in 1991 prices. 
Source: Statistika Meddelanden. Serie N, various issues.

\section{Participation in Training Schemes}

The proportion of 16-19 year olds (not disaggregated by gender) participating in Labour Market Training.

Source: Labour market statistics from Arbetsmarknadsstyrelsen.

\section{England and Wales}

\section{Proportion of age group in the post-compulsory education}

The numbers of 16 year olds, 17 year olds and 18 year olds in England and Wales, in education at schools, sixth form colleges, tertiary colleges and other further education institutions, expressed as a proportion of the relevant age group. Age is taken as age on the $1^{\text {st }}$ of September in each year. Before 1979, official statistics were given based on age on the $1^{\text {st }}$ of January. However, some data is provided for the maintained school sector, giving the numbers participating based on age at both dates. These data were used to calculate multipliers to convert the numbers based on age on the $1^{\text {st }}$ of January, to numbers based on age on the $1^{\text {st }}$ of September, for all those in education. Separate series were collected for males and females, and the numbers were expressed as a proportion of the relevant age cohort.

Sources: Welsh Office, Statistics of Education in Wales, 1977/78-1993/94. Department for Education, Participation in Education by 16-18 Year Olds in England : 1983/84-1993/94. Statistical Bulletin, 10/94.

Department for Education, Participation in Education by 16-18 Year Olds in England : 1979/801992/93. Statistical Bulletin, 16/93. Department of Education and Science, Statistics of Education vol 1: Schools (England and Wales) , 1961/2-1978/79. Department of Education and Science, Statistics of Education vol 3: Further Education (England and Wales) , 1961/2$1978 / 79$.

\section{Youth unemployment rate}

The proportion of 18 and 19 year olds unemployed, according to the claimant count. Pre-1970, only the numbers unemployed, rather than the proportion, are given. The number of 18 and 19 year olds in the labour force is therefore calculated from total labour force statistics, together with the proportions in each age group, available in the British Labour Statistics Historical Abstract.

Sources: Department of Employment, Department of Employment Gazette, 1961-1994. Department of Employment, British Labour Statistics Historical Abstract.

\section{Ratio of professional to manual earnings}

Since 1970, the New Earnings Survey has provided data on earnings by occupation. Professional workers are defined as Groups 1 and 2 in the 1990 Standard Occupational Classification. From 
1970 to 1990, data on the occupations covered by these groups is used. Prior to 1970, the British Labour Statistics Historical Abstract is used, which provides earnings data for 'administrative, professional and technical staff' in the public sector, banking and insurance. Data on average manual earnings are similarly taken from the New Earnings Survey since 1970, and the British Labour Statistics Historical Abstract prior to that date.

Sources: Department of Employment, New Earnings Survey, 1970-1994. Department of Employment, British Labour Statistics Historical Abstract.

\section{Real per capita consumer expenditure}

Total household expenditure per head of the population, expressed in 1956 prices.

Sources: Cental Statistical Office, Annual Abstract of Statistics, 1961-1994.

\section{GCSE success}

The proportions of those aged 16 and under who pass 5 GCSEs at grade $\mathrm{C}$ or above, of the equivalent of this in earlier years.

Sources: Department for Education, Statistics of Education, vol 2: School Examinations Survey/School Leavers Survey, !961/62-1990/91. Department of Education and Science, Statistics of Education: School Examinations, GCSE and GCE 1989-1991. Department of Education and Science, Statistics of Education: Public Examinations, GCSE and GCE 19891991.

\section{Proportion of 16 year olds participating in youth training schemes}

The proportion of 16 year olds participating in the Youth Training Scheme, or Youth Training. This variable takes the value of zero prior to 1979. It refers only to England.

Sources: Department of Education and Science, 'Educational and Economic Activity of Young People Aged 16 to 18 Years in England from 1974/75 to 1989/90,' Statistical Bulletin, 13/91. Department for Employment and Education, 'Participation in Education and Training by 16-18 Year Olds in England 1985-1995, DfEE News, 213/96. 


\section{References}

Ashford, S., Gray, J. and Tranmer, M. (1993) 'The introduction of GCSE Exams and Changes in Post-16 Participation,' Employment Department Research Series, Youth Cohort Report no. 23.

Blanchflower, D. and Freeman, R. (1996) 'Growing into Work,' Centre for Economic Performance Discussion Paper no 296, London School of Economics.

Cheng, Y. (1995) 'Staying on in Full-Time Education After 16: Do Schools Make a Difference?' Employment Department Research Series, Youth Cohort Report no. 37.

Dickey, D. A. and Fuller, W. A. (1981) 'Likelihood Ratio Statistics for Autoregressive Time Series with a Unit Root,' Econometrica, 49, 1057-1072.

Engle, R. and Granger, C. (1987) 'Co-integration and Error Correction: Representations, Estimation and Testing,' Econometrica, 55, 251-276.

Glyn, A. (1995) 'The Assessment: Unemployment and Inequality,' Oxford Review of Economic Policy,' 11, 1-25.

Granger, C. and Newbold, P. (1974) 'Spurious Regressions in Econometrics,' Journal of Econometrics, 2, 111-120.

Gray, J., Jesson, D. and Tranmer, M. (1993) 'Boosting Post-16 Participation in Full-Time Education. A Study of Some Key Factors,' Employment Department Research Series, Youth Cohort Report no. 20.

Gray, J., Jesson, D. and Tranmer, M. (1994) 'Local Labour Market Variations in Post-16 Participation: Evidence from the End of the Eighties,' Employment Department Research Series, Youth Cohort Report no. 26.

Murray, A. (1997) 'Young People Without an Upper Secondary Education in Sweden: Their Home Background, School and Labour Market Experiences,' Scandinavian Journal of Educational Research, 41, 93-125.

Pissarides, C.A. (1981) 'Staying-on at School in England and Wales,' Economica, 48, 345-363.

Rudd, P. (1997) 'I have a Dream. Young People's Job Expectations in Two Contrasting Labour Markets,' Centre for Economic Performance mimeo, London School of Economics.

Whitfield, K. and Wilson, R.A. (1991) 'Staying on in Full-time Education: The Educational Participation Rate of 16-year-olds,' Economica, 58, 391-404. 